\title{
Reviewing global estimates of surface reactive nitrogen concentration and deposition using satellite retrievals
}

\author{
Lei Liu ${ }^{1}$, Xiuying Zhang ${ }^{2}$, Wen $\mathrm{Xu}^{3}$, Xuejun Liu ${ }^{3}$, Xuehe $\mathrm{Lu}^{2}$, Jing Wei ${ }^{4,5}$, Yi Li ${ }^{6}$, Yuyu Yang ${ }^{1}$, Zhen Wang ${ }^{2}$, and \\ Anthony Y. H. Wong ${ }^{7}$ \\ ${ }^{1}$ College of Earth and Environmental Sciences, Lanzhou University, Lanzhou, 730000, China \\ ${ }^{2}$ International Institute for Earth System Science, Nanjing University, Nanjing, 210023, China \\ ${ }^{3}$ College of Resources and Environmental Sciences, National Academy of Agriculture Green Development, \\ China Agricultural University, Beijing, 100193, China \\ ${ }^{4}$ State Key Laboratory of Remote Sensing Science, College of Global Change and Earth System Science, \\ Beijing Normal University, Beijing, China \\ ${ }^{5}$ Department of Atmospheric and Oceanic Science, Earth System Science Interdisciplinary Center, \\ University of Maryland, College Park, MD, USA \\ ${ }^{6}$ Chief Technology Officer SailBri Cooper Inc., Beaverton, OR 97008, USA \\ ${ }^{7}$ Department of Earth and Environment, Boston University, Boston, MA 02215, USA
}

Correspondence: Lei Liu (liuleigeo@1zu.edu.cn)

Received: 31 January 2020 - Discussion started: 24 February 2020

Revised: 18 June 2020 - Accepted: 29 June 2020 - Published: 22 July 2020

\begin{abstract}
Since the industrial revolution, human activities have dramatically changed the nitrogen $(\mathrm{N})$ cycle in natural systems. Anthropogenic emissions of reactive nitrogen $\left(\mathrm{N}_{\mathrm{r}}\right)$ can return to the earth's surface through atmospheric $\mathrm{N}_{\mathrm{r}}$ deposition. Increased $\mathrm{N}_{\mathrm{r}}$ deposition may improve ecosystem productivity. However, excessive $\mathrm{N}_{\mathrm{r}}$ deposition can cause a series of negative effects on ecosystem health, biodiversity, soil, and water. Thus, accurate estimations of $\mathrm{N}_{\mathrm{r}}$ deposition are necessary for evaluating its environmental impacts. The United States, Canada and Europe have successively launched a number of satellites with sensors that allow retrieval of atmospheric $\mathrm{NO}_{2}$ and $\mathrm{NH}_{3}$ column density and therefore estimation of surface $\mathrm{N}_{\mathrm{r}}$ concentration and deposition at an unprecedented spatiotemporal scale. Atmosphere $\mathrm{NH}_{3}$ column can be retrieved from atmospheric infra-red emission, while atmospheric $\mathrm{NO}_{2}$ column can be retrieved from reflected solar radiation. In recent years, scientists attempted to estimate surface $\mathrm{N}_{\mathrm{r}}$ concentration and deposition using satellite retrieval of atmospheric $\mathrm{NO}_{2}$ and $\mathrm{NH}_{3}$ columns. In this study, we give a thorough review of recent advances of estimating surface $\mathrm{N}_{\mathrm{r}}$ concentration and deposition using the satellite retrievals of $\mathrm{NO}_{2}$ and $\mathrm{NH}_{3}$, present a framework of using satellite data to estimate surface $\mathrm{N}_{\mathrm{r}}$ con-
\end{abstract}

centration and deposition based on recent works, and summarize the existing challenges for estimating surface $\mathrm{N}_{\mathrm{r}}$ concentration and deposition using the satellite-based methods. We believe that exploiting satellite data to estimate $\mathrm{N}_{\mathrm{r}}$ deposition has a broad and promising prospect.

\section{Introduction}

Nitrogen $(\mathrm{N})$ exists in three forms in the environment, including reactive nitrogen $\left(\mathrm{N}_{\mathrm{r}}\right)$, organic nitrogen $(\mathrm{ON})$ and nitrogen gas $\left(\mathrm{N}_{2}\right)$ (Canfield et al., 2010). $\mathrm{N}_{2}$ is the main component of air, accounting for $78 \%$ of the total volume of air, but it cannot be directly used by most plants. $\mathrm{N}_{\mathrm{r}}$ refers to the general term of $\mathrm{N}$-containing substances in the atmosphere, plants, soils and fertilizers that are not combined with carbon. $\mathrm{N}_{\mathrm{r}}$ (such as $\mathrm{NO}_{3}^{-}$and $\mathrm{NH}_{4}^{+}$) is the main form of $\mathrm{N}$ that can be directly used by most plants, but the content of $\mathrm{N}_{\mathrm{r}}$ in nature is much lower compared with $\mathrm{ON}$ and $\mathrm{N}_{2}$ (Vitousek et al., 1997; Nicolas and Galloway, 2008). The supply of $\mathrm{N}_{\mathrm{r}}$ is essential for all life forms and contributes to the increase in agricultural production, thus providing sufficient food for the growing global population (Galloway et al., 2008, 2014b; 
David et al., 2013; Erisman et al., 2008). Before the industrial revolution, $\mathrm{N}_{\mathrm{r}}$ mainly came from natural sources such as biological $\mathrm{N}$ fixation, lightning and volcanic eruption (Galloway et al., 2004a). Since the industrial revolution, human activities (e.g., agricultural development, combustion of fossil energy) have greatly perturbed the $\mathrm{N}$ cycle in natural systems (Canfield et al., 2010; Kim et al., 2014; Lamarque et al., 2005).

$\mathrm{N}_{\mathrm{r}}\left(\mathrm{NO}_{x}\right.$ and $\left.\mathrm{NH}_{3}\right)$ emitted to the atmosphere will return to the earth's surface through atmospheric deposition (Liu et al., 2011). Atmospheric $\mathrm{N}_{\mathrm{r}}$ deposition refers to the process in which $\mathrm{N}_{\mathrm{r}}$ is removed from the atmosphere, including wet (rain and snow) and dry (gravitational settling, atmospheric turbulence, etc.) deposition (Xu et al., 2015; Zhang et al., 2012; Pan et al., 2012). The input of $\mathrm{N}_{\mathrm{r}}$ over terrestrial natural ecosystems primarily comes from the $\mathrm{N}_{\mathrm{r}}$ deposition (Shen et al., 2013; Sutton et al., 2001; Larssen et al., 2011). In the short term, atmospheric $\mathrm{N}_{\mathrm{r}}$ deposition can increase the $\mathrm{N}_{\mathrm{r}}$ input to ecosystems, which promotes plant growth and enhances ecosystem productivity (Erisman et al., 2008). However, excessive atmospheric $\mathrm{N}_{\mathrm{r}}$ deposition also causes a series of environmental problems (X. Liu et al., 2017). Due to the low efficiency of agricultural $\mathrm{N}$ application, plenty of $\mathrm{N}_{\mathrm{r}}$ is lost through runoff, leaching and volatilization, causing serious environmental pollution. Excessive $\mathrm{N}_{\mathrm{r}}$ deposition may aggravate the plant's susceptibility to drought or frost, reduce the resistance of the plant to pathogens or pests, and further affect the physiology and biomass distribution of vegetation (ratio of roots, stems and leaves) (Stevens et al., 2004; Nadelhoffer et al., 1999; Bobbink et al., 2010; Janssens et al., 2010). Excessive $\mathrm{N}_{\mathrm{r}}$ leads to eutrophication and related algal blooms over aquatic ecosystems, reducing water biodiversity (Paerl et al., 2014), while excessive $\mathrm{N}_{\mathrm{r}}$ in drinking water also poses a threat to human health (Zhao et al., 2013; Wei et al., 2019). Therefore, monitoring and estimation of surface $N_{r}$ concentration and deposition on the global scale are of great importance and urgency.

The methods of estimating atmospheric $\mathrm{N}_{\mathrm{r}}$ deposition can be divided into three categories: ground-based monitoring, atmospheric chemical transport modeling (ACTM) and satellite-based estimation. Ground-based monitoring is considered to be the most accurate and quantitative method, which can effectively reflect the $\mathrm{N}_{\mathrm{r}}$ deposition in local areas. ACTM can simulate the processes of $\mathrm{N}_{\mathrm{r}}$ chemical reaction, transport, and deposition, as well as the vertical distribution of $\mathrm{N}_{\mathrm{r}}$. Satellite-based estimation establishes empirical, physical or semi-empirical models by connecting the groundbased $\mathrm{N}_{\mathrm{r}}$ concentrations and deposition with satellite-derived $\mathrm{N}_{\mathrm{r}}$ concentration. This study focuses on reviewing the recent development of satellite-based methods to estimate $\mathrm{N}_{\mathrm{r}}$ deposition. Since the estimation of $\mathrm{N}_{\mathrm{r}}$ concentrations is just a part of the estimation of dry $\mathrm{N}_{\mathrm{r}}$ depositions, we here mainly reviewed the progress of dry $\mathrm{N}_{\mathrm{r}}$ depositions using the satellite observation. We firstly give a brief introduction to the progress of ground-based monitoring and ACTM- based methods and then present a detailed framework of using satellite observation to estimate dry and wet $\mathrm{N}_{\mathrm{r}}$ deposition (including both oxidized and reduced $\mathrm{N}_{\mathrm{r}}$ ). Next, we review the recent advances of the satellite-based methods of estimating $\mathrm{N}_{\mathrm{r}}$ deposition. Finally, we discuss the remaining challenges for estimating surface $\mathrm{N}_{\mathrm{r}}$ concentration and deposition using satellite observation.

\section{Methods for estimating surface $\mathrm{N}_{\mathrm{r}}$ concentration and deposition}

\subsection{Ground-based monitoring}

Ground-based monitoring of $\mathrm{N}_{\mathrm{r}}$ deposition can be divided into two parts: wet and dry $\mathrm{N}_{\mathrm{r}}$ deposition monitoring. Since the 1970s, there have been large-scale monitoring networks focusing on the wet $\mathrm{N}_{\mathrm{r}}$ deposition. The main large-scale regional monitoring networks include the Canadian Air and Precipitation Monitoring Network (CAPMoN), Acid Deposition Monitoring Network in East Asia (EANET), European Monitoring and Evaluation Program (EMEP), United States National Atmospheric Deposition Program (NADP), World Meteorological Organization Global Atmosphere Watch Precipitation Chemistry Program, and Nationwide Nitrogen Deposition Monitoring Network in China (NNDMN) (Tan et al., 2018; Vet et al., 2014). The detailed scientific objectives of the wet $\mathrm{N}_{\mathrm{r}}$ deposition observation networks vary, but most of the observation networks mainly concentrate on the spatiotemporal variation of wet deposition of ions including $\mathrm{N}_{\mathrm{r}}$ compounds, the long-term trends of ions in precipitation, and the evaluation of ACTMs.

Compared with wet $\mathrm{N}_{\mathrm{r}}$ deposition monitoring, dry $\mathrm{N}_{\mathrm{r}}$ deposition monitoring started late, due to the limitation of monitoring technology since it is more difficult to be quantified (affected greatly by surface roughness, air humidity, climate and other environmental factors) (Liu et al., 2017c). Dry $\mathrm{N}_{\mathrm{r}}$ deposition observation networks include the US ammonia monitoring network (AMoN), CAPMoN, EANET and EMEP. The monitoring methods of dry $\mathrm{N}_{\mathrm{r}}$ deposition are mainly divided into direct monitoring (such as dynamic chambers) and indirect monitoring (such as inferential methods). The inferential model is widely applied in groundbased monitoring networks (such as EANET and NNDMN), mainly because this method is more practical and simpler. In inferential models, dry deposition is divided into two parts: surface $\mathrm{N}_{\mathrm{r}}$ concentrations and the deposition velocity $\left(V_{\mathrm{d}}\right)$ of $\mathrm{N}_{\mathrm{r}}$ (Nowlan et al., 2014). $V_{\mathrm{d}}$ can be estimated by meteorology, land use types of the underlying surface as well as the characteristics of each $\mathrm{N}_{\mathrm{r}}$ component itself using resistance models (Nemitz et al., 2001). Thus, dry $\mathrm{N}_{\mathrm{r}}$ deposition monitoring networks only need to focus on the quantification of surface concentration of individual $\mathrm{N}_{\mathrm{r}}$ components. The $\mathrm{N}_{\mathrm{r}}$ components in the atmosphere are very complex, including $\mathrm{N}_{2} \mathrm{O}_{5}, \mathrm{HONO}, \mathrm{NH}_{3}, \mathrm{NO}_{2}, \mathrm{HNO}_{3}$ and particulate $\mathrm{NH}_{4}^{+}$ 
and $\mathrm{NO}_{3}^{-}$. Most monitoring networks include the major $\mathrm{N}_{\mathrm{r}}$ species such as gaseous $\mathrm{NH}_{3}, \mathrm{NO}_{2}, \mathrm{HNO}_{3}$ and the particles of $\mathrm{NH}_{4}^{+}$and $\mathrm{NO}_{3}^{-}$.

Efforts of ground-based $\mathrm{N}_{\mathrm{r}}$ deposition monitoring are mostly concentrated on wet $\mathrm{N}_{\mathrm{r}}$ deposition, while observations of dry $\mathrm{N}_{\mathrm{r}}$ deposition are relatively scarce, especially for surface $\mathrm{HNO}_{3}$ and $\mathrm{NH}_{4}^{+}$and $\mathrm{NO}_{3}^{-}$. Second, most observation networks focus on a few years or a certain period of time, leading to the lack of long-term continuously monitoring on both wet and dry $\mathrm{N}_{\mathrm{r}}$ deposition. More importantly, the global $\mathrm{N}_{\mathrm{r}}$ deposition monitoring network has not been established, and the sampling standards in different regions are not unified. These outline the potential room for improvement of ground-based $\mathrm{N}_{\mathrm{r}}$ deposition monitoring.

\subsection{Atmospheric Chemistry Transport Model (ACTM) simulation}

An ACTM can simulate $\mathrm{N}_{\mathrm{r}}$ deposition at regional or global scales by explicitly representing the physical and chemical processes of atmospheric $\mathrm{N}_{\mathrm{r}}$ components (Zhao et al., 2017; Zhang et al., 2012). Wet $\mathrm{N}_{\mathrm{r}}$ deposition flux is parameterized as in-cloud, under-cloud and precipitation scavenging (Amos et al., 2012; Levine and Schwartz, 1982; Liu et al., 2001; Mari et al., 2000), while dry deposition flux can be obtained as the product of surface $\mathrm{N}_{\mathrm{r}}$ concentration and $V_{\mathrm{d}}$, which is typically parameterized as a network of resistances (Wesely and Hicks, 1977). Based on the integrated results of 11 models of HTAP (hemispheric transport of air pollution), Tan et al. (2018) found that about $76 \%-83 \%$ of the ACTM's simulation results were $\pm 50 \%$ of the monitoring values, and the modeling results underestimated the wet deposition of $\mathrm{NH}_{4}^{+}$ and $\mathrm{NO}_{3}^{-}$over Europe and East Asia and overestimated the wet deposition of $\mathrm{NO}_{3}^{-}$over the eastern US (Tan et al., 2018). Though regional ACTMs can be configured at very high horizontal resolution (e.g., $1 \times 1 \mathrm{~km}^{2}$ ) (Kuik et al., 2016), the horizontal resolutions of global ACTMs are relatively coarse $\left(1^{\circ} \times 1^{\circ}-5^{\circ} \times 4^{\circ}\right)$ (Williams et al., 2017), which cannot indicate the local pattern of $\mathrm{N}_{\mathrm{r}}$ deposition. On the other hand, the $\mathrm{N}_{\mathrm{r}}$ emission inventory used to drive an ACTM is highly uncertain, with the uncertainty of the $\mathrm{NO}_{x}$ emission at about $\pm 30 \%-40 \%$ and that of $\mathrm{NH}_{3}$ emission at about $\pm 30 \%-$ $80 \%$ (Zhang et al., 2009; Cao et al., 2011).

\subsection{Satellite-based estimation of surface $\mathrm{N}_{\mathbf{r}}$ concentration and deposition}

Satellite observation has wide spatial coverages and high resolution and is spatiotemporally continuous. Atmospheric $\mathrm{NO}_{2}$ and $\mathrm{NH}_{3}$ columns can be derived from satellite measurements with relatively high accuracy (Van Damme et al., 2015; Boersma et al., 2011), providing a new perspective about atmospheric $\mathrm{N}_{\mathrm{r}}$ abundance.

Satellite instruments that can monitor $\mathrm{NO}_{2}$ in the atmosphere include GOME (Global Ozone Monitoring Ex- perience), SCIAMACHY (SCanning Imaging Absorption SpectroMeter for Atmospheric ChartographY), OMI (Ozone Monitoring Instrument), and GOME-2 (Global Ozone Monitoring Experience-2). Some scholars applied satellite $\mathrm{NO}_{2}$ columns to estimate the surface $\mathrm{NO}_{2}$ concentration and then dry $\mathrm{NO}_{2}$ deposition by combining the surface $\mathrm{NO}_{2}$ concentration and modeled $V_{\mathrm{d}}$. Cheng et al. (2013) established a statistical model to estimate the surface $\mathrm{NO}_{2}$ concentration based on the SCIAMACHY $\mathrm{NO}_{2}$ columns and then estimated the dry deposition of $\mathrm{NO}_{2}$ over eastern China (Cheng et al., 2013). This method used the simple linear model and did not consider the vertical profiles of $\mathrm{NO}_{2}$ (Cheng et al., 2013). Lu et al. (2013) established a multivariate linear regression model based on the SCIAMACHY and GOME $\mathrm{NO}_{2}$ columns, meteorological data and ground-based monitoring $\mathrm{N}_{\mathrm{r}}$ deposition and then estimated the global total $\mathrm{N}_{\mathrm{r}}$ deposition (Lu et al., 2013). Lu et al. (2013) could not distinguish the contribution of dry and wet $\mathrm{N}_{\mathrm{r}}$ deposition using the multivariate linear regression model (Lu et al., 2013). Jia et al. (2016) established a simple linear regression model based on OMI tropospheric $\mathrm{NO}_{2}$ column and ground-based surface $\mathrm{N}_{\mathrm{r}}$ concentration and then estimated the total amounts of dry $\mathrm{N}_{\mathrm{r}}$ deposition (Jia et al., 2016). Jia et al. (2016) used the OMI tropospheric $\mathrm{NO}_{2}$ column to estimate the dry deposition of reduced $\mathrm{N}_{\mathrm{r}}$ deposition $\left(\mathrm{NH}_{3}\right.$ and $\mathrm{NH}_{4}^{+}$), which could also bring great errors since the $\mathrm{OMI} \mathrm{NO}_{2}$ column could not indicate the $\mathrm{NH}_{3}$ emission. These studies highlight the problem of using only $\mathrm{NO}_{2}$ columns to derive total $\mathrm{N}_{\mathrm{r}}$ deposition: that $\mathrm{NO}_{2}$ columns give us highly limited information about the abundance of reduced $\mathrm{N}_{\mathrm{r}}\left(\mathrm{NH}_{3}\right.$ and $\left.\mathrm{NH}_{4}^{+}\right)$.

Lamsal et al. (2008) first used the relationship between the $\mathrm{NO}_{2}$ column and surface $\mathrm{NO}_{2}$ concentration at the bottom layer simulated by an ACTM to convert the OMI $\mathrm{NO}_{2}$ column to surface $\mathrm{NO}_{2}$ concentration (Lamsal et al., 2008). A series of works (Lamsal et al., 2013; Nowlan et al., 2014; Kharol et al., 2018) have effectively estimated the regional and global surface $\mathrm{NO}_{2}$ concentration using the satellite $\mathrm{NO}_{2}$ column combined with the ACTM-derived relationship between the $\mathrm{NO}_{2}$ column and surface $\mathrm{NO}_{2}$ concentration simulated. It is worth mentioning that Nowlan et al. (2014) applied the OMI $\mathrm{NO}_{2}$ column to obtain the global dry $\mathrm{NO}_{2}$ deposition during 2005-2007 for the first time (Nowlan et al., 2014). However, using the satellite $\mathrm{NO}_{2}$ column and ACTMderived relationship between the $\mathrm{NO}_{2}$ column and surface $\mathrm{NO}_{2}$ concentration may lead to an underestimation of surface $\mathrm{NO}_{2}$ concentration. Kharol et al. (2015) found that the satellite-derived surface $\mathrm{NO}_{2}$ concentration using the above method is only half of the observed values (Kharol et al., 2015). To resolve such potential underestimation, Larkin et al. (2017) established a statistical relationship between the satellite-derived and ground-measured surface $\mathrm{NO}_{2}$ concentration and then calibrated the satellite-derived surface $\mathrm{NO}_{2}$ concentration using the established relationship (Larkin et al., 2017). 
Some researchers also estimated other $\mathrm{N}_{\mathrm{r}}$ components ( such as particulate $\mathrm{NO}_{3}^{-}$) based on the satellite $\mathrm{NO}_{2}$ column. Based on the linear model between $\mathrm{NO}_{2}, \mathrm{NO}_{3}^{-}$, and $\mathrm{HNO}_{3}$ obtained by ground-based measurements, Jia et al. (2016) calculated the surface $\mathrm{NO}_{3}^{-}$and $\mathrm{HNO}_{3}$ concentration using satellite-derived surface $\mathrm{NO}_{2}$ concentration and their relationship (Jia et al., 2016). Geddes et al. (2016) reconstructed the $\mathrm{NO}_{x}$ emission data by using the satellite $\mathrm{NO}_{2}$ column and then estimated the global $\mathrm{NO}_{x}$ deposition by an ACTM, but the spatial resolution of global $\mathrm{NO}_{x}$ deposition remains low $\left(2^{\circ} \times 2.5^{\circ}\right)$, failing to exploit the higher resolution of satellite observation (Geddes and Martin, 2017).

Compared with $\mathrm{NO}_{2}$, the development of satellite $\mathrm{NH}_{3}$ monitoring is relatively late. Atmospheric $\mathrm{NH}_{3}$ was first detected by the TES in Beijing and Los Angeles (Beer et al., 2008). The IASI sensor also detected atmospheric $\mathrm{NH}_{3}$ from a biomass burning event in Greece (Coheur et al., 2009). Subsequently, many scholars began to develop more reliable satellite $\mathrm{NH}_{3}$ column retrievals (Whitburn et al., 2016; Van Damme et al., 2015), validate the satellite-retrieved $\mathrm{NH}_{3}$ column with the ground-based observation (Van Damme et al., 2015; Dammers et al., 2016; Li et al., 2017), and compare the satellite $\mathrm{NH}_{3}$ column with the aircraft-measured $\mathrm{NH}_{3}$ column (Van Damme et al., 2014; Whitburn et al., 2016). In recent years, some scholars have carried out the works of estimating surface $\mathrm{NH}_{3}$ concentration based on the satellite $\mathrm{NH}_{3}$ column. Liu et al. (2017) obtained the satellite-derived surface $\mathrm{NH}_{3}$ concentration in China based on the IASI $\mathrm{NH}_{3}$ column coupled with an ACTM and deepened the understanding of the spatial pattern of surface $\mathrm{NH}_{3}$ concentration in China (Liu et al., 2017b). Similarly, Van der Graaf et al. (2018) carried out the relevant work in Europe based on the IASI $\mathrm{NH}_{3}$ column coupled with an ACTM and estimated the dry $\mathrm{NH}_{3}$ deposition in western Europe (Van der Graaf et al., 2018). Jia et al. (2016) first constructed the linear model between surface $\mathrm{NO}_{2}$ and $\mathrm{NH}_{4}^{+}$concentration based on ground monitoring data and then calculated the $\mathrm{NH}_{4}^{+}$concentration using the satellite-derived surface $\mathrm{NO}_{2}$ concentration and their relationship (Jia et al., 2016). However, as the emission sources of $\mathrm{NO}_{x}$ (mainly from the transportation and energy sectors) and $\mathrm{NH}_{3}$ (mainly from the agricultural sector) are different (Hoesly et al., 2018), the linear model between surface $\mathrm{NO}_{2}$ and $\mathrm{NH}_{4}^{+}$concentration may lead to large uncertainties in estimating the global $\mathrm{NH}_{4}^{+}$concentration. There is still no report about the satellite-derived dry and wet-reduced $\mathrm{N}_{\mathrm{r}}$ deposition using the satellite $\mathrm{NH}_{3}$ column at a global scale. As reduced $\mathrm{N}_{\mathrm{r}}$ plays an important role in total $\mathrm{N}_{\mathrm{r}}$ deposition, satellite $\mathrm{NH}_{3}$ should be better utilized to help estimate reduced $\mathrm{N}_{\mathrm{r}}$ deposition.

\subsection{Problems in estimating global $\mathrm{N}_{\mathrm{r}}$ deposition}

The spatial coverage of ground monitoring sites focusing on $\mathrm{N}_{\mathrm{r}}$ deposition is still not adequate, and the monitoring standards and specifications in different regions of the world are not consistent, presenting a barrier to integrating different regional monitoring data. Large uncertainties exist in the $\mathrm{N}_{\mathrm{r}}$ emission inventory used to drive the ACTMs, and the spatial resolution of the modeled $\mathrm{N}_{\mathrm{r}}$ deposition by ACTMs is coarse. Using satellite monitoring data to estimate surface $\mathrm{N}_{\mathrm{r}}$ concentration and deposition is still in its infancy, especially for reduced $\mathrm{N}_{\mathrm{r}}$.

Some scholars tried to use the satellite $\mathrm{NO}_{2}$ and $\mathrm{NH}_{3}$ column to estimate the surface $\mathrm{N}_{\mathrm{r}}$ concentration and dry $\mathrm{N}_{\mathrm{r}}$ deposition. However, there are relatively few studies on estimating wet $\mathrm{N}_{\mathrm{r}}$ deposition. In addition, the development of satellite monitoring for $\mathrm{NH}_{3}$ in the atmosphere is relatively late (compared with $\mathrm{NO}_{2}$ ). At present, IASI $\mathrm{NH}_{3}$ data have been widely used, while the effective measurements of TES are less than IASI; CrIS and AIRS $\mathrm{NH}_{3}$ column products are still under development. There are three main concerns in high-resolution estimation of surface $\mathrm{N}_{\mathrm{r}}$ concentration and deposition based on satellite $\mathrm{N}_{\mathrm{r}}$ observation. (1) How to effectively couple the satellite high-resolution $\mathrm{NO}_{2}$ and $\mathrm{NH}_{3}$ column data with the vertical profiles simulated by an ACTM and then estimate the surface $\mathrm{N}_{\mathrm{r}}$ concentrations? This step is the key to simulating the dry $\mathrm{N}_{\mathrm{r}}$ deposition. (2) How to construct a model for estimating dry $\mathrm{N}_{\mathrm{r}}$ deposition including all major $\mathrm{N}_{\mathrm{r}}$ species based on the satellite $\mathrm{NO}_{2}$ and $\mathrm{NH}_{3}$ column and then for estimating the dry $\mathrm{N}_{\mathrm{r}}$ deposition at a high spatial resolution? (3) How to combine the high-resolution satellite $\mathrm{NO}_{2}$ and $\mathrm{NH}_{3}$ column data and ground-based monitoring data to construct wet $\mathrm{N}_{\mathrm{r}}$ deposition models and then estimate the wet $\mathrm{N}_{\mathrm{r}}$ deposition at a high spatial resolution?

\section{Framework of estimating surface $\mathbf{N}_{\mathbf{r}}$ concentration and deposition using satellite observation}

Previous studies using satellite observation to estimate surface $\mathrm{N}_{\mathrm{r}}$ concentration and deposition only focused on one or several $\mathrm{N}_{\mathrm{r}}$ components, but did not include all $\mathrm{N}_{\mathrm{r}}$ components, which were decentralized, unsystematic and incomplete. Here we give a framework of using satellite observation to estimate surface $\mathrm{N}_{\mathrm{r}}$ concentration and deposition as shown in Fig. 1 based on recent advances.

\subsection{Conversion of the satellite $\mathrm{NO}_{2}$ and $\mathrm{NH}_{3}$ column to surface $\mathrm{N}_{\mathbf{r}}$ concentration}

An ACTM can simulate the vertical profiles of $\mathrm{NO}_{2}$ and $\mathrm{NH}_{3}$ with multiple layers from the surface to the troposphere. For example, the GEOS-Chem ACTM includes 47 vertical layers from the earth's surface to the top of the stratosphere. Most previous studies estimated the ratio of surface $\mathrm{N}_{\mathrm{r}}$ concentration (at the first layer) to total columns by an ACTM and then multiply the ratio by satellite columns to estimate satellite-derived surface concentration (Geddes et al., 2016; Van der Graaf et al., 2018; Nowlan et al., 2014). 

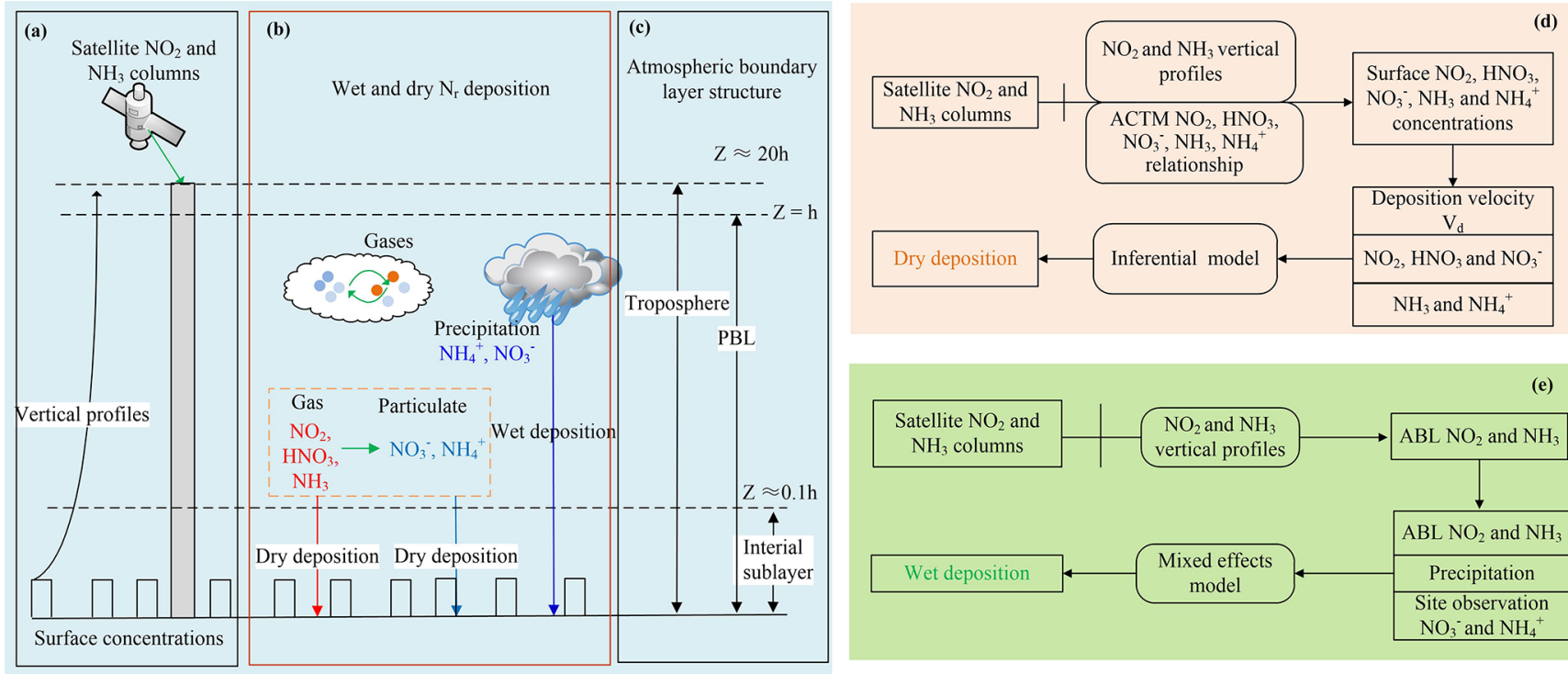

(d)

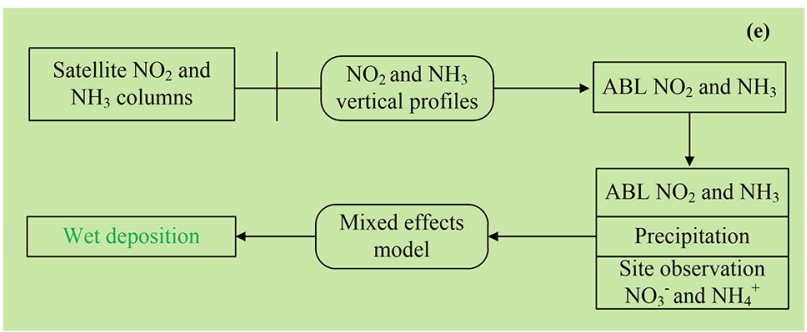

Figure 1. Schematic diagram of dry and wet $\mathrm{N}_{\mathrm{r}}$ deposition. (a) indicates the satellite-observed $\mathrm{NO}_{2}$ and $\mathrm{NH}_{3}$ column and the vertical profiles by an ACTM; (b) shows dry and wet $\mathrm{N}_{\mathrm{r}}$ deposition including the major $\mathrm{N}_{\mathrm{r}}$ species (gaseous $\mathrm{NO}_{2}, \mathrm{HNO}_{3}, \mathrm{NH}_{3}$, particulate $\mathrm{NO}_{3}^{-}$and $\mathrm{NH}_{4}^{+}$, as well as wet $\mathrm{NO}_{3}^{-}$and $\mathrm{NH}_{4}^{+}$in precipitation); (c) illustrates atmospheric vertical structures including the troposphere (satellite observation), atmospheric boundary layer (ABL), and interfacial sub-layer; (d) and (e) represent procedures of calculating the dry and wet $\mathrm{N}_{\mathrm{r}}$ deposition.

Another approach tries to fit general vertical profiles of $\mathrm{NO}_{2}$ and $\mathrm{NH}_{3}$ (Zhang et al., 2017; Liu et al., 2017b, c) and then estimate the ratio of $\mathrm{N}_{\mathrm{r}}$ concentration at any height to total $\mathrm{N}_{\mathrm{r}}$ columns and finally multiply the ratio by satellite $\mathrm{NO}_{2}$ and $\mathrm{NH}_{3}$ columns. This approach has an advantage compared with the previous one because $\mathrm{NO}_{2}$ and $\mathrm{NH}_{3}$ concentration at all altitudes included in ACTM simulations can be estimated. Satellite $\mathrm{NO}_{2}$ and $\mathrm{NH}_{3}$ column data had no vertical profiles. Surface $\mathrm{NO}_{2}$ and $\mathrm{NH}_{3}$ concentration was estimated by modeled $\mathrm{NO}_{2}$ and $\mathrm{NH}_{3}$ vertical profiles from the CTM. The Gaussian model was constructed to fit the multiple layers' $\mathrm{NO}_{2}$ and $\mathrm{NH}_{3}$ concentrations with the altitude. The constructed Gaussian model has general rules, appropriate for converting satellite columns to surface concentration simply.

Taking the estimation of surface $\mathrm{NO}_{2}$ concentration using the latter approach as an example, the methods and steps are introduced in the following.

- Step 1: calculate the monthly mean $\mathrm{NO}_{2}$ concentrations at all layers simulated by an ACTM.

- Step 2: construct the vertical profile function of $\mathrm{NO}_{2}$. Multiple Gaussian functions are used to fit the vertical distribution of $\mathrm{NO}_{2}$ based on the monthly $\mathrm{NO}_{2}$ concentrations at all layers calculated in Step 1, in which the independent variable is the height (altitude) and the dependent variable is $\mathrm{NO}_{2}$ concentration at a certain height.

The basic form of the single Gaussian function is (Zhang et al., 2017; Liu et al., 2017b, c; Whitburn et al., 2016)

$\rho=\rho_{\max } e^{-\left(\frac{Z-Z_{0}}{\sigma}\right)^{2}}$,

where $Z$ is the height of a layer in the ACTM; $\rho_{\max }$, $Z_{0}$ and $\sigma$ are the maximum $\mathrm{NO}_{2}$ concentration, the corresponding height with the maximum $\mathrm{NO}_{2}$ concentration and the thickness of the $\mathrm{NO}_{2}$ concentration layer (1 standard error of the Gaussian function).

There are two basic forms of profile shapes of $\mathrm{NO}_{2}$ : (1) $\mathrm{NO}_{2}$ concentration reaches the maximum concentration when reaching a certain height $\left(Z_{\mathrm{o}} \neq 0\right)$. As the height increases, the $\mathrm{NO}_{2}$ concentration begins to decline; (2) $\mathrm{NO}_{2}$ concentration is basically concentrated on the earth's surface $\left(Z_{0}=0\right)$. These two cases are the ideal state of the vertical distribution of $\mathrm{NO}_{2}$ concentration. In reality, single Gaussian fitting may not capture the vertical distribution of $\mathrm{NO}_{2}$ well. To improve the accuracy of fitting, the sum of multiple Gaussian functions can be used (Liu et al., 2019):

$\rho(Z)=\sum_{i=1}^{n} \rho_{\max , i} e^{-\left(\frac{Z-Z_{0, i}}{\sigma_{i}}\right)^{2}}$.

- Step 3: calculate the ratio of $\mathrm{NO}_{2}$ concentration at the height of $h_{\mathrm{G}}$ to total columns $\left(\int_{0}^{h_{\text {trop }}} \rho(Z) \mathrm{d} x\right)$ and then multiply the ratio by the satellite column $\left(S_{\text {trop }}\right)$. The satellite-derived $\mathrm{N}_{\mathrm{r}}$ concentration at the height of $h_{\mathrm{G}}$ can be calculated as

$S_{\mathrm{G}_{-} \mathrm{NO} 2}=S_{\text {trop }} \times \frac{\rho\left(h_{\mathrm{G}}\right)}{\int_{0}^{h_{\text {trop }}} \rho(Z) \mathrm{d} x}$. 
- Step 4: convert the instantaneous satellite-derived surface $\mathrm{NO}_{2}$ concentration $\left(S_{\mathrm{G}_{-} \mathrm{NO} 2}\right)$ to the daily average $\left(S_{\mathrm{G}_{\mathrm{N}} \mathrm{NO} 2}^{*}\right)$ using the ratio of average surface $\mathrm{NO}_{2}$ concentration $\left(G_{\mathrm{ACTM}}^{1-24}\right)$ to that at satellite overpass time $\left(G_{\mathrm{ACTM}}^{\text {overpass }}\right)$ by an ACTM (Liu et al., 2020):

$S_{\mathrm{G} \_\mathrm{NO} 2}^{*=} \frac{G_{\mathrm{ACTM}}^{1-24}}{G_{\text {ACTM }}^{\text {overpass }}} \times S_{\mathrm{G} \_\mathrm{NO} 2}$.

The method for estimating the surface $\mathrm{NH}_{3}$ concentration $\left(S_{\mathrm{G}_{-} \mathrm{NH} 3}^{*}\right)$ is similar to that for estimating the surface $\mathrm{NO}_{2}$ concentration.

\subsection{Estimating surface concentrations of other $N_{r}$ species}

At present, only the $\mathrm{NO}_{2}$ and $\mathrm{NH}_{3}$ column can be retrieved reliably, and there are no reliable satellite retrievals of $\mathrm{HNO}_{3}$, $\mathrm{NH}_{4}^{+}$and $\mathrm{NO}_{3}^{-}$. For example, the IASI $\mathrm{HNO}_{3}$ product is still in the stage of data development and verification (Ronsmans et al., 2016). Previous studies firstly derive the relationship between $\mathrm{N}_{\mathrm{r}}$ species by an ACTM or by ground-based measurements and then use the relationship to convert satellitederived surface $\mathrm{NO}_{2}$ and $\mathrm{NH}_{3}$ concentration $\left(\mathrm{S}_{\mathrm{G}_{-} \mathrm{NH}}^{*}\right.$ ) to $\mathrm{HNO}_{3}, \mathrm{NH}_{4}^{+}$and $\mathrm{NO}_{3}^{-}$concentrations:

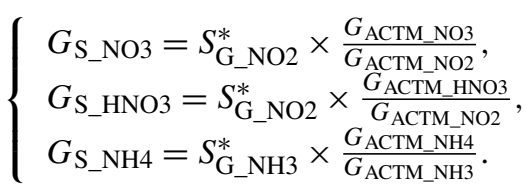

$\frac{G_{\text {ACTM_NO3 }}}{G_{\text {ACTM_NO2 }}}, \frac{G_{\text {ACTM_HNO3 }}}{G_{\text {ACTM_NO2 }}}$, and $\frac{G_{\text {ACTM_NH4 }}}{G_{\text {ACTM_NH3 }}}$ are the estimated ratios between $\mathrm{NO}_{2}$ and $\mathrm{NO}_{3}^{-}, \mathrm{NO}_{2}$ and $\mathrm{HNO}_{3}$, and $\mathrm{NH}_{3}$ and $\mathrm{NH}_{4}^{+}$.

\subsection{Dry deposition of $\mathbf{N}_{\mathbf{r}}$}

The resistance of dry $\mathrm{N}_{\mathrm{r}}$ deposition mainly comes from three aspects: aerodynamic resistance $\left(R_{\mathrm{a}}\right)$, quasi laminar sublayer resistance $\left(R_{\mathrm{b}}\right)$ and canopy resistance $\left(R_{\mathrm{C}}\right)$. The $V_{\mathrm{d}}$ can be expressed as

$V_{\mathrm{d}}=\frac{1}{R_{\mathrm{a}}+R_{\mathrm{b}}+R_{\mathrm{c}}}+v_{\mathrm{g}}$

$V_{\mathrm{g}}$ is gravitational settling velocity. For gases, the $V_{\mathrm{g}}$ is negligible $\left(V_{\mathrm{g}}=0\right)$.

Dry $\mathrm{NO}_{2}, \mathrm{NO}_{3}^{-}, \mathrm{HNO}_{3}$, and $\mathrm{NH}_{4}^{+}$deposition can be calculated by

$F=G_{\mathrm{S}} \times V_{\mathrm{d}}$.

Unlike the above species, $\mathrm{NH}_{3}$ is bi-directional, presenting both upward and downward fluxes. There is a so-called "canopy compensation point" $\left(C_{\mathrm{o}}\right)$ controlling dry $\mathrm{NH}_{3}$ deposition. Dry $\mathrm{NH}_{3}$ deposition can be calculated by

$F=\left(G_{\mathrm{S}_{-} \mathrm{NH} 3}-C_{\mathrm{o}}\right) \times V_{\mathrm{d}}$.
The calculation of $C_{\mathrm{o}}$ is very complex, including the leaf stomatal and soil emission potentials related to the meteorological factors, the plant growth stage and the canopy type. The satellite-based methods usually neglected this complex process and set $C_{\mathrm{o}}$ as zero (Van der Graaf et al., 2018; Kharol et al., 2018) or set fixed values in each land use type based on ground-based measurements (Jia et al., 2016).

\subsection{Wet deposition of $\mathbf{N}_{\mathbf{r}}$}

The satellite-based estimation of wet $\mathrm{N}_{\mathrm{r}}$ deposition can be simplified as the product of the concentration of $\mathrm{N}_{\mathrm{r}}(C)$, precipitation $(P)$ and scavenging coefficient $(w)$ (Pan et al., 2012). Satellite $\mathrm{NO}_{2}$ and $\mathrm{NH}_{3}$ can be used to indicate the oxidized $\mathrm{N}_{\mathrm{r}}$ and reduced $\mathrm{N}_{\mathrm{r}}$; precipitation $(P)$ can be obtained from ground monitoring data or reanalysis data (such as NCEP). However, the scavenging coefficient $(w)$ is usually highly uncertain. To improve the accuracy of estimation, a mixed-effects model (Liu et al., 2017a; Zhang et al., 2018) is proposed to build the relationship between satellite $\mathrm{NO}_{2}$ and $\mathrm{NH}_{3}$, precipitation and ground monitoring wet $\mathrm{N}_{\mathrm{r}}$ deposition:

$\operatorname{WetN}_{i j}=\alpha_{j}+\beta_{i} \times P_{i j} \times\left(S_{\mathrm{ABL}}\right)_{i j}+\varepsilon_{i j}$,

$S_{\mathrm{ABL}}=S_{\text {trop }} \times \frac{\int_{0}^{\mathrm{ABL}} \rho(Z) \mathrm{d} x}{\int_{0}^{h_{\text {trop }}} \rho(Z) \mathrm{d} x}$.

WetN $\mathrm{N}_{i j}$ is wet $\mathrm{NO}_{3}^{-} \mathrm{N}$ or $\mathrm{NH}_{4}^{+}-\mathrm{N}$ deposition at month $i$ and site $j ;\left(\mathrm{S}_{\mathrm{ABL}}\right)_{\mathrm{ij}}$ is the atmospheric boundary layer (ABL) $\mathrm{NO}_{2}$ or $\mathrm{NH}_{3}$ columns at month $i$ and site $j ; P_{i j}$ is precipitation at month $i$ and site $j ; \beta_{i}$ and $\alpha_{j}$ are the slope and intercept of random effects, representing seasonal variability and spatial effects, and $\varepsilon_{i j}$ represents the random error at month $i$ and site $j$. The mixed-effects models were appropriate for estimating both wet $\mathrm{NO}_{3}^{-}$and $\mathrm{NH}_{4}^{+}$deposition using the satellite observations.

The scavenging process of wet $\mathrm{N}_{\mathrm{r}}$ deposition usually starts from the height of rainfall rather than the top of the troposphere, so it is more reasonable to use the $\mathrm{NO}_{2}$ and $\mathrm{NH}_{3}$ column below the height of rainfall to build the wet $\mathrm{N}_{\mathrm{r}}$ deposition model. The $\mathrm{NO}_{2}$ and $\mathrm{NH}_{3}$ column within the ABL is used to build the wet deposition model since precipitation height is close to the height of the ABL (generally less than 2-3 km).

\section{Satellite-derived surface $N_{r}$ concentration and deposition}

\subsection{Surface $\mathrm{NO}_{2}$ concentration and oxidized $\mathrm{N}_{\mathrm{r}}$ deposition}

The spatial resolutions of global ACTMs and therefore modeled surface $\mathrm{N}_{\mathrm{r}}$ concentration are very coarse (for example, the spatial resolution of the global version of GEOS-Chem 
is $2^{\circ} \times 2.5^{\circ}$ ). Thus it can be hard to estimate surface $\mathrm{N}_{\mathrm{r}}$ concentration and deposition at a fine resolution at a global scale by ACTMs alone. Instead, the satellite $\mathrm{N}_{\mathrm{r}}$ retrievals have a high spatial resolution and can reveal more spatial details than ACTM simulations.

Cheng et al. (2013) and Jia et al. (2016) established a linear model between the surface $\mathrm{NO}_{2}$ concentration and $\mathrm{NO}_{2}$ column by assuming the ratio of the surface $\mathrm{NO}_{2}$ concentration to the tropospheric $\mathrm{NO}_{2}$ column to be fixed, then used the linear model to convert satellite $\mathrm{NO}_{2}$ columns to surface $\mathrm{NO}_{2}$ concentration, and finally estimated dry $\mathrm{NO}_{2}$ deposition using the inferential method (Cheng et al., 2013; Jia et al., 2016). However, these statistical methods are highly dependent on the ground-based measurements, and the established linear models may be ineffective over regions with few monitoring sites.

A comprehensive study (Nowlan et al., 2014) estimated global surface $\mathrm{NO}_{2}$ concentration during 2005-2007 by multiplying OMI tropospheric $\mathrm{NO}_{2}$ columns by the ACTMmodeled ratio between the surface $\mathrm{NO}_{2}$ concentration and tropospheric column (Fig. 2). Nowlan et al. (2014) also estimated dry $\mathrm{NO}_{2}$ deposition using the OMI-derived surface $\mathrm{NO}_{2}$ concentration by combining the modeled $V_{\mathrm{d}}$ during 2005-2007 (Nowlan et al., 2014). This approach followed an earlier study (Lamsal et al., 2008) that focused on North America. As reported by Lamsal et al., the satellite-derived surface $\mathrm{NO}_{2}$ concentration was generally lower than groundbased $\mathrm{NO}_{2}$ observations, ranging from $-17 \%$ to $-36 \%$ in North America (Lamsal et al., 2008). Kharol et al. (2015) used a similar method and found the satellite-derived surface $\mathrm{NO}_{2}$ concentration was only half of the ground-measured values in North America (Kharol et al., 2015).

Geddes et al. (2016) followed previous studies and used the $\mathrm{NO}_{2}$ column from GOME, SCIAMACHY, and GOME-2 to estimate surface $\mathrm{NO}_{2}$ concentration (Geddes et al., 2016). Although Geddes et al. (2016) did not evaluate their results with ground-based observation (Geddes et al., 2016), it is obvious that their surface $\mathrm{NO}_{2}$ estimates were higher than Nowlan's estimates based on OMI (Nowlan et al., 2014) (Fig. 2). This may be because the OMI-derived $\mathrm{NO}_{2}$ column is much lower than that derived by GOME, SCIAMACHY, and GOME-2, especially over polluted regions. For example, in China, the OMI NO $\mathrm{N}_{2}$ column is about $30 \%$ lower than that of SCIAMACHY and GOME-2 consistently (Fig. 3).

Larkin et al. (2017) established a land use regression model to estimate global surface $\mathrm{NO}_{2}$ concentration by combining satellite-derived surface $\mathrm{NO}_{2}$ concentration by Geddes et al. (2016) and ground-based annual $\mathrm{NO}_{2}$ measurements (Geddes et al., 2016; Larkin et al., 2017). The study by Larkin et al. (2017) can be considered to use the groundbased annual measurements to adjust the satellite-derived surface $\mathrm{NO}_{2}$ concentration by Geddes et al. (2016), which helped reduce the discrepancy between satellite-derived and ground-measured $\mathrm{NO}_{2}$ concentration. The regression model captured $54 \%$ of global $\mathrm{NO}_{2}$ variation, with an absolute error of $2.32 \mu \mathrm{g} \mathrm{N} \mathrm{m}{ }^{-3}$.

Zhang et al. (2017) followed the framework in Sect. 3 to estimate the OMI-derived surface $\mathrm{NO}_{2}$ concentration (at $\sim 50 \mathrm{~m}$ ) in China and found good agreement with groundbased surface $\mathrm{NO}_{2}$ concentration from the NNDMN at a yearly scale (slope $=1.00, R^{2}=0.89$ ) (Zhang et al., 2017). The methods by Zhang et al. (2017) can also generate OMIderived $\mathrm{NO}_{2}$ concentration at any height by the constructed $\mathrm{NO}_{2}$ vertical profile (Zhang et al., 2017). Zhang et al. (2017) also estimated dry $\mathrm{NO}_{2}$ deposition using the OMI-derived surface $\mathrm{NO}_{2}$ concentration by combining the modeled $V_{\mathrm{d}}$ during 2005-2016 (Zhang et al., 2017). Based on Zhang's estimates, the Gaussian function can well simulate the vertical distribution of $\mathrm{NO}_{2}$ from an ACTM (MOZART) (Emmons et al., 2010), with $99.64 \%$ of the grids having $R^{2}$ values higher than 0.99. This suggests that the ACTM-simulated vertical distribution of $\mathrm{NO}_{2}$ has a general pattern, which can be emulated by Gaussian functions. Once a vertical profile has been constructed, it can be easily used to estimate $\mathrm{NO}_{2}$ concentration at any height.

In this study, we used the framework in Sect. 3 to estimate the OMI-derived surface $\mathrm{NO}_{2}$ concentration globally. To validate the OMI-derived surface $\mathrm{NO}_{2}$ concentrations, groundmeasured surface $\mathrm{NO}_{2}$ concentration in China, the US and Europe in 2014 was collected (Fig. 4). The total number of $\mathrm{NO}_{2}$ observations in China, the US and Europe are 43, 373 and 88 , respectively. The OMI-derived annual average for all sites was $3.74 \mu \mathrm{g} \mathrm{N} \mathrm{m}^{-3}$, which was close to the measured average $\left(3.06 \mu \mathrm{g} \mathrm{N} \mathrm{m}^{-3}\right)$. The $R^{2}$ between OMI-derived surface $\mathrm{NO}_{2}$ concentrations and ground-based $\mathrm{NO}_{2}$ measurements was 0.75 and the RMSE was $1.23 \mu \mathrm{g} \mathrm{N} \mathrm{m}^{-3}$ (Fig. 5), which is better than the modeling results by the GEOSChem ACTM $\left(R^{2}=0.43, \operatorname{RMSE}=1.93 \mu \mathrm{g} \mathrm{N} \mathrm{m}^{-3}\right)$. We did not simply use the relationship between the $\mathrm{NO}_{2}$ column and surface $\mathrm{NO}_{2}$ concentration from the CTM. As presented in the methods, we can estimate surface $\mathrm{NO}_{2}$ concentration at any height by using the Gaussian function. We used the surface $\mathrm{NO}_{2}$ concentration at a certain height $(\sim 60 \mathrm{~m})$ which best matched with the ground-based measurements. Satellitebased methods have the advantages of spatiotemporally continuous monitoring $\mathrm{N}_{\mathrm{r}}$ at a higher resolution, which helps alleviate the problem of the coarse resolution of ACTMs in estimating $\mathrm{N}_{\mathrm{r}}$ concentration and deposition. The readers can use any satellite data (GOME, SCIAMACHY, GOME2 or OMI) combining the Gaussian function to estimate surface $\mathrm{NO}_{2}$ concentrations. They can use surface $\mathrm{NO}_{2}$ concentrations at a certain height which best matched with the groundbased measurements. The key is not selecting which satellite data we should use, but determining which height of surface $\mathrm{NO}_{2}$ concentrations better matched with the ground-based measurements by a Gaussian function.

For $\mathrm{NO}_{3}^{-}$and $\mathrm{HNO}_{3}$, previous studies firstly constructed the relationship between $\mathrm{NO}_{2}, \mathrm{NO}_{3}^{-}$and $\mathrm{HNO}_{3}$ and found a relatively high linear relationship between $\mathrm{NO}_{2}, \mathrm{NO}_{3}^{-}$, and 
(a) Surface $\mathrm{NO}_{2}$ during $2005-2007$ by Nowlan et al. (2014)

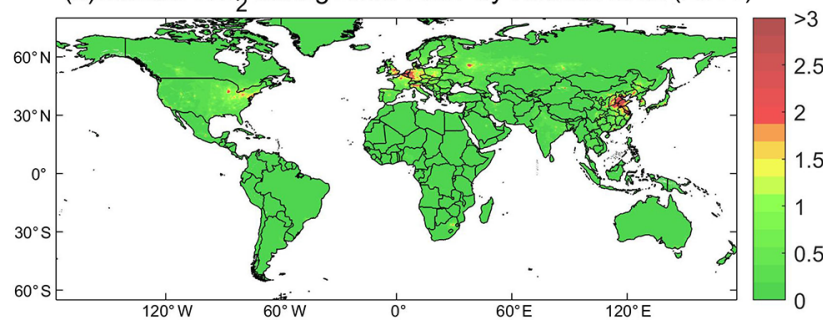

(b) Surface $\mathrm{NO}_{2}$ during $2005-2007$ by Geddes et al. (2016)

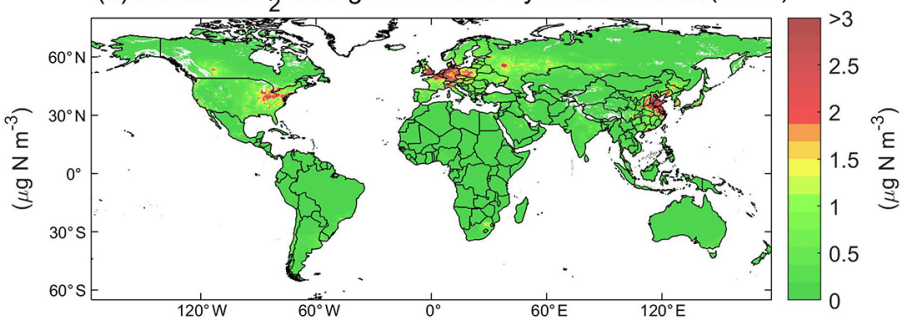

Figure 2. Satellite-derived surface $\mathrm{NO}_{2}$ concentration during 2005-2007 by Nowlan et al. (2014) (a) and by Geddes et al. (2016) (b). We gained the surface $\mathrm{NO}_{2}$ concentration by Nowlan et al. (2014) and by Geddes et al. (2016) at the website: http://fizz.phys.dal.ca/ atmos/ martin/?page_id=232, last access: 17 July 2020.

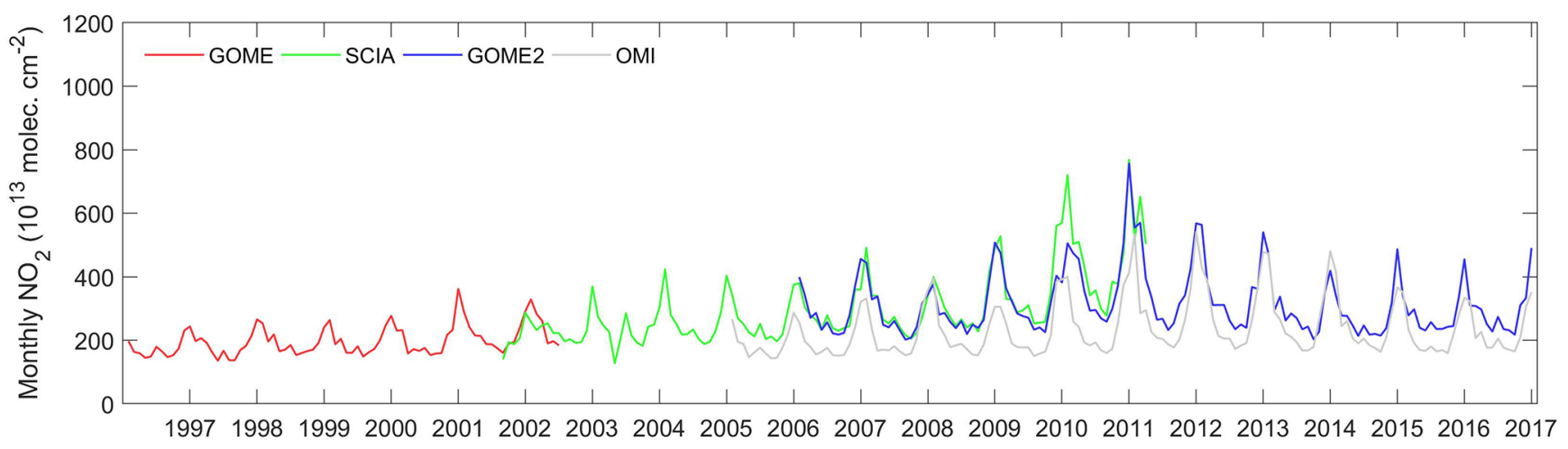

Figure 3. An example of the time series of the monthly $\mathrm{NO}_{2}$ column retrieved by GOME, SCIAMACHY, GOME2 and OMI in China. We obtained the GOME, SCIAMACHY, GOME2 and OMI data from http://www.temis.nl/airpollution/no2.html, last access: 17 July 2020.

$\mathrm{HNO}_{3}$ at a monthly or yearly scale. For example, Jia et al. (2016) found a linear relationship between $\mathrm{NO}_{2}, \mathrm{NO}_{3}^{-}$, and $\mathrm{HNO}_{3}$ concentration at an annual scale $\left(R^{2}=0.70\right)(\mathrm{Jia}$ et al., 2016). Similarly, based on the ground-based measurements in the NNDMN, a high correlation was found between surface $\mathrm{NO}_{2}$ and $\mathrm{NO}_{3}^{-}$concentration at monthly or annual timescales (Fig. 6) (Liu et al., 2017c). Using these linear relationships and satellite-derived surface $\mathrm{NO}_{2}$ concentration, the annual mean surface $\mathrm{NO}_{3}^{-}$and $\mathrm{HNO}_{3}$ can be estimated. Alternatively, the relationship of $\mathrm{NO}_{2}, \mathrm{NO}_{3}^{-}$and $\mathrm{HNO}_{3}$ can also be modeled by an ACTM. For example, a strong relationship of the tropospheric $\mathrm{NO}_{2}, \mathrm{NO}_{3}^{-}$and $\mathrm{HNO}_{3}$ column was simulated over all months by an ACTM, with the correlation ranging from 0.69 to 0.91 (Liu et al., 2017a). But, over shorter timescales, the relationship between $\mathrm{NO}_{2}, \mathrm{NO}_{3}^{-}$and $\mathrm{HNO}_{3}$ may be nonlinear, which we should be cautious about when estimating surface $\mathrm{NO}_{3}^{-}$and $\mathrm{HNO}_{3}$ concentration from $\mathrm{NO}_{2}$ concentration.

For the wet $\mathrm{N}_{\mathrm{r}}$ deposition, Liu et al. (2017a) followed the framework in Sect. 3 to estimate wet nitrate deposition using ABL $\mathrm{NO}_{2}$ columns derived from an $\mathrm{OMI} \mathrm{NO} 2$ column and $\mathrm{NO}_{2}$ vertical profile from an ACTM (MOZART), and precipitation by a mixed-effects model showing the proposed model can achieve high predictive power for monthly wet ni- trate deposition over China $(R=0.83, \mathrm{RMSE}=0.72)(\mathrm{Liu}$ et al., 2017a).

\subsection{Surface $\mathrm{NH}_{3}$ concentration and reduced $\mathrm{N}_{\mathrm{r}}$ deposition}

With the development of atmospheric remote sensing of $\mathrm{NH}_{3}$, some scholars have estimated surface $\mathrm{NH}_{3}$ concentration and dry $\mathrm{NH}_{3}$ deposition based on the satellite $\mathrm{NH}_{3}$ column data. Assuming the ratio between the surface $\mathrm{NH}_{3}$ concentration to the $\mathrm{NH}_{3}$ column was fixed, Yu et al. (2019) applied a linear model to convert satellite $\mathrm{NH}_{3}$ columns to surface $\mathrm{NH}_{3}$ concentration and estimated dry $\mathrm{NH}_{3}$ deposition in China using the inferential method (Yu et al., 2019). But Yu et al. (2019) did not consider the spatial variability of the vertical profiles of $\mathrm{NH}_{3}$ (Yu et al., 2019), which may cause a large uncertainty in estimating surface $\mathrm{NH}_{3}$ concentration.

In western Europe, Van der Graaf et al. (2018) used the ratio of the surface $\mathrm{NH}_{3}$ concentration (in the bottom layer) to total $\mathrm{NH}_{3}$ column from an ACTM to convert the IASI $\mathrm{NH}_{3}$ column to surface $\mathrm{NH}_{3}$ concentration and then estimated dry $\mathrm{NH}_{3}$ deposition by combining the modeled deposition velocity and IASI-derived surface $\mathrm{NH}_{3}$ concentration (Van der Graaf et al., 2018). Similarly, in North America, Kharol et al. (2018) estimated the dry $\mathrm{NH}_{3}$ deposition by the CrIS- 

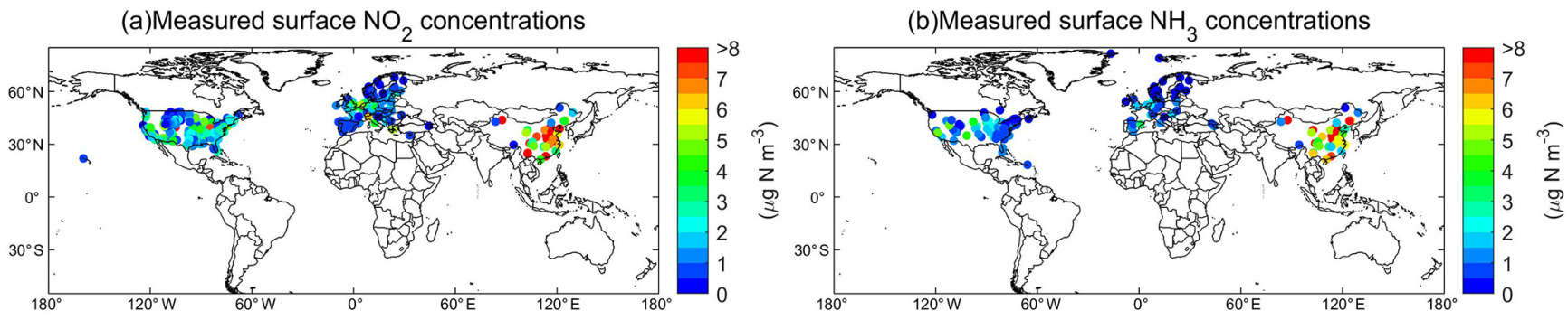

Figure 4. Spatial distribution of measured surface $\mathrm{NO}_{2}$ and $\mathrm{NH}_{3}$ concentrations in 2014. For $\mathrm{NO}_{2}$ (a), the measured data in China, the US and Europe were obtained from the NNDMN, US-EPA and EMEP, respectively; for $\mathrm{NH}_{3}$ (b), the measured data in China, the US and Europe were obtained from the NNDMN, US-AMoN and EMEP, respectively.
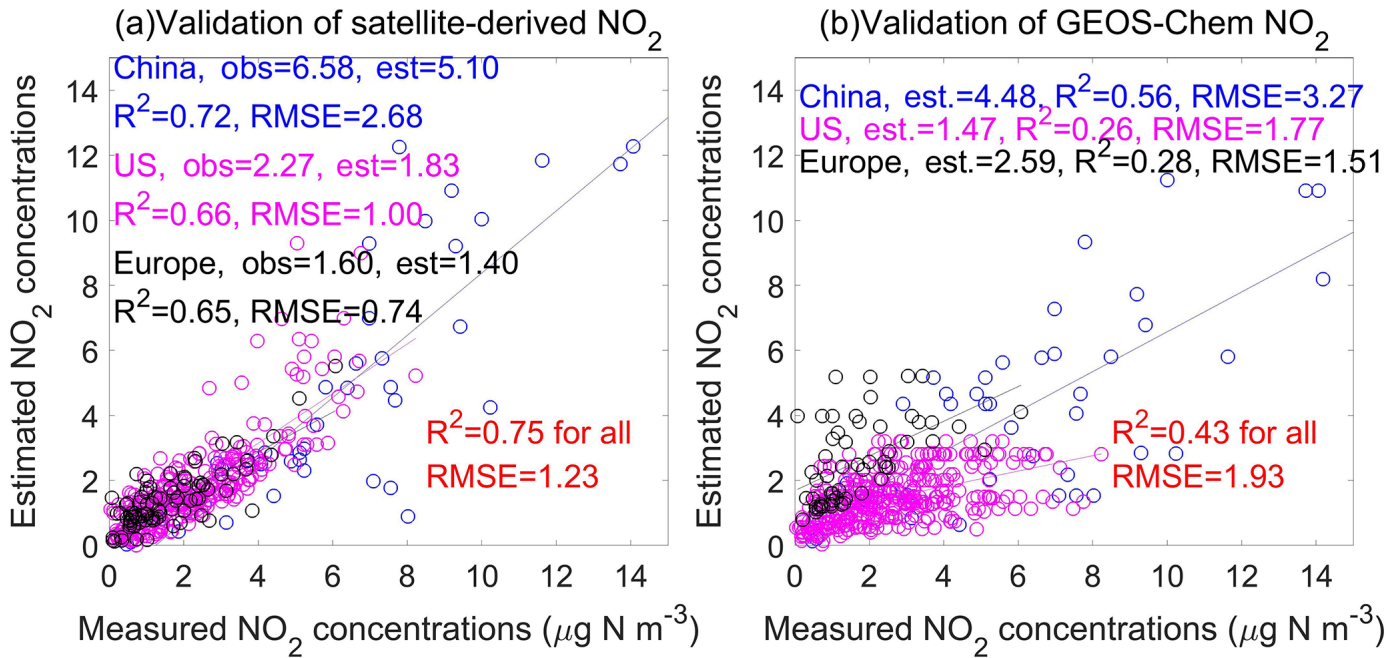

Figure 5. Comparison between annual mean satellite-derived and ground-measured surface $\mathrm{NO}_{2}$ concentrations (a) and comparison between annual mean modeled (by an ACTM as GEOS-Chem) and ground-measured surface $\mathrm{NO}_{2}$ concentrations (b). The ground-based monitoring sites are shown in Fig. 4.

derived surface $\mathrm{NH}_{3}$ concentration and deposition velocity of $\mathrm{NH}_{3}$ (Kharol et al., 2018). They found a relatively high correlation $(R=0.76)$ between the CrIS-derived surface $\mathrm{NH}_{3}$ concentration and $\mathrm{AMoN}$ measurements during warm seasons (from April to September) in 2013 (Fig. 7). Over China, Liu et al. (2017b) found a higher correlation $(R=0.81)$ between IASI-derived surface $\mathrm{NH}_{3}$ concentrations and the measured surface $\mathrm{NH}_{3}$ concentrations than those from an $\operatorname{ACTM}(R=0.57$, Fig. 8$)$ (Liu et al., 2017b).

Liu et al. (2019) followed the framework in Sect. 3 to estimate the IASI-derived surface $\mathrm{NH}_{3}$ concentration (at the middle height of the first layer by an ACTM) (Fig. 9) and found a good agreement with ground-based surface $\mathrm{NH}_{3}$ concentration (Liu et al., 2019). The correlation between the measured and satellite-derived annual mean surface $\mathrm{NH}_{3}$ concentrations over all sites was 0.87 as shown in Fig. 10, while the average satellite-derived and ground-measured surface $\mathrm{NH}_{3}$ concentrations were 2.52 and $2.51 \mu \mathrm{g} \mathrm{N} \mathrm{m}^{-3}$ in 2014 at the monitoring sites, respectively. The satellite-derived estimates achieved a bet- ter accuracy $\left(R^{2}=0.76\right.$, RMSE $\left.=1.50 \mu \mathrm{g} \mathrm{N} \mathrm{m}^{-3}\right)$ than an ACTM (GEOS-Chem, $R^{2}=0.54$, RMSE $=2.14 \mu \mathrm{g} \mathrm{N} \mathrm{m}^{-3}$ ). The satellite $\mathrm{NH}_{3}$ retrievals were affected by the detection limits of the satellite instruments and thermal contrast. Higher correlation over China than other regions for the satellite estimates was linked to the detection limits by the instruments and thermal contrast (Liu et al., 2019). Higher accuracy could be gained with higher thermal contrast and $\mathrm{NH}_{3}$ abundance. Instead, the uncertainties of $\mathrm{NH}_{3}$ retrievals would be higher with lower thermal contrast and $\mathrm{NH}_{3}$ abundance.

The proposed methods (Liu et al., 2019) can also estimate $\mathrm{NH}_{3}$ concentration at any height using the constructed vertical profile function of $\mathrm{NH}_{3}$. The Gaussian function can well emulate the vertical distribution of $\mathrm{NH}_{3}$ from an ACTM output, with $99 \%$ of the grids having $R^{2}$ values higher than 0.90 (Fig. 11). This means, for regional and global estimation, the vertical distribution of $\mathrm{NH}_{3}$ concentration has a general pattern, which can be mostly emulated by the Gaussian function. Once a global $\mathrm{NH}_{3}$ vertical profile was simulated, it can be 


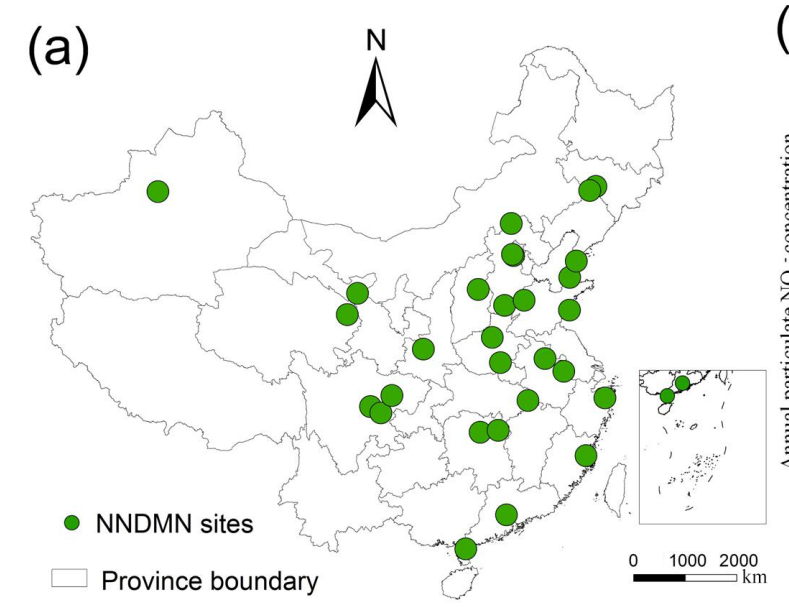

(b)
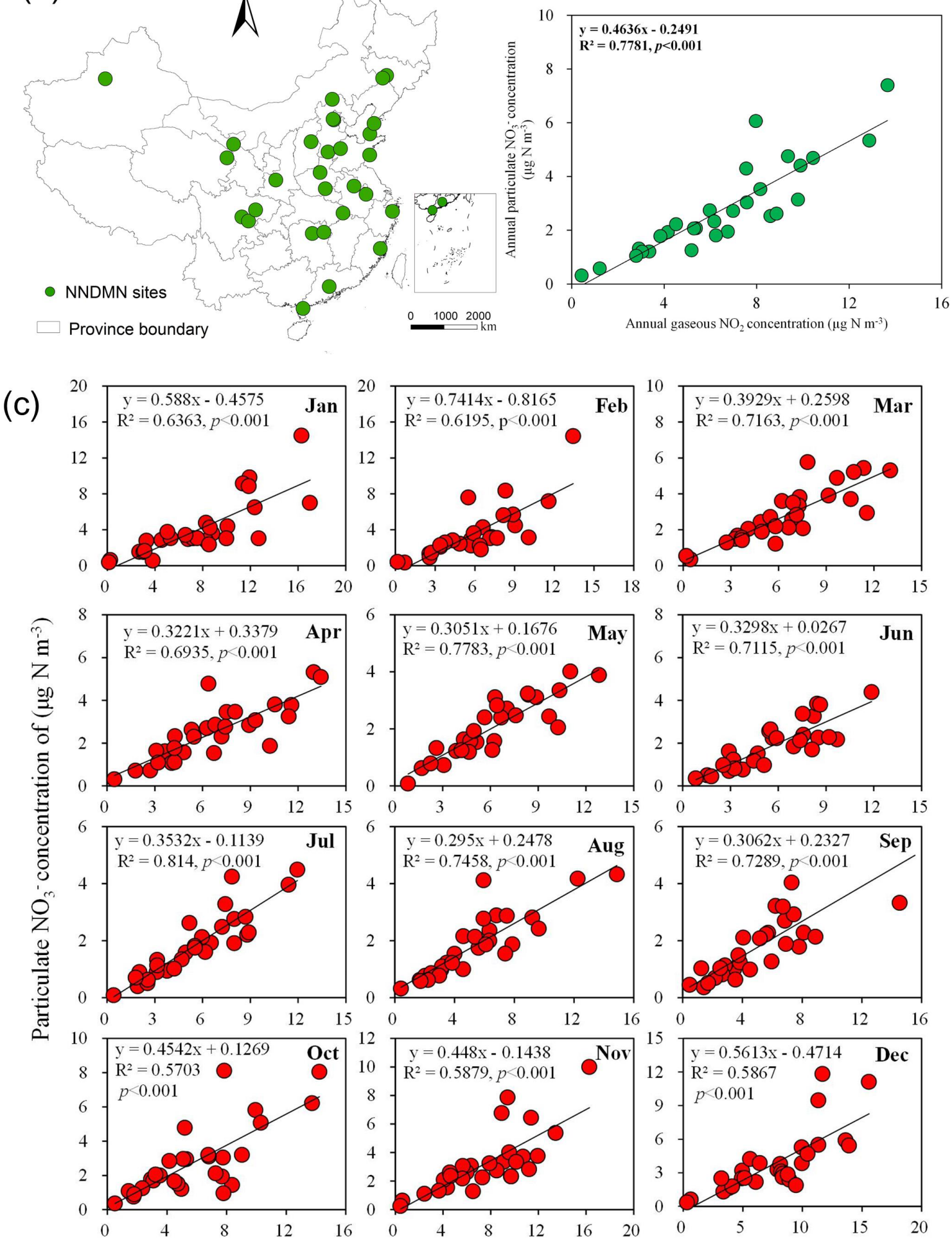

Gaseous $\mathrm{NO}_{2}$ concentration $\left(\mu \mathrm{g} \mathrm{N} \mathrm{m}{ }^{-3}\right)$

Figure 6. Correlation between surface $\mathrm{NO}_{2}$ and particulate $\mathrm{NO}_{3}^{-}$concentration in the NNDMN at annual and monthly scales, which were adopted from our previous study (Liu et al., 2017c). (a) indicates the spatial locations of monitoring sites in the NNDMN; (b) and (c) represent yearly and monthly relationships between surface $\mathrm{NO}_{2}$ and particulate $\mathrm{NO}_{3}^{-}$concentration, respectively. 
(a)

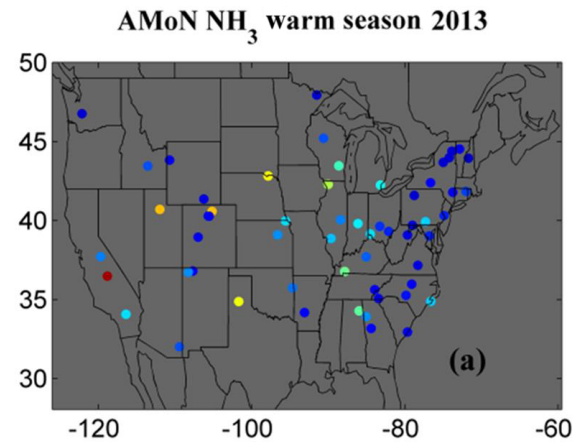

(c)

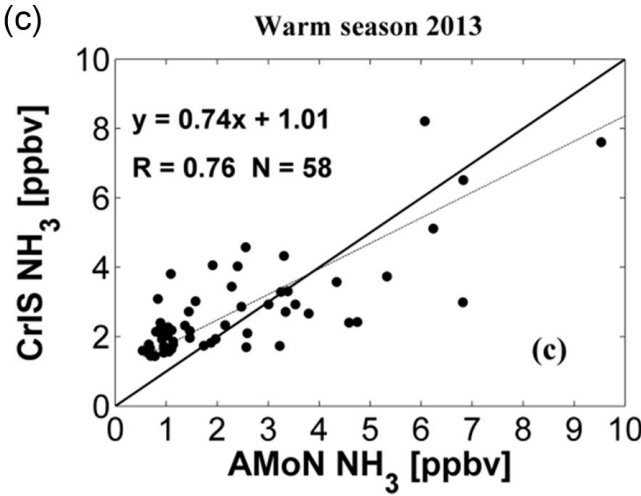

(b)
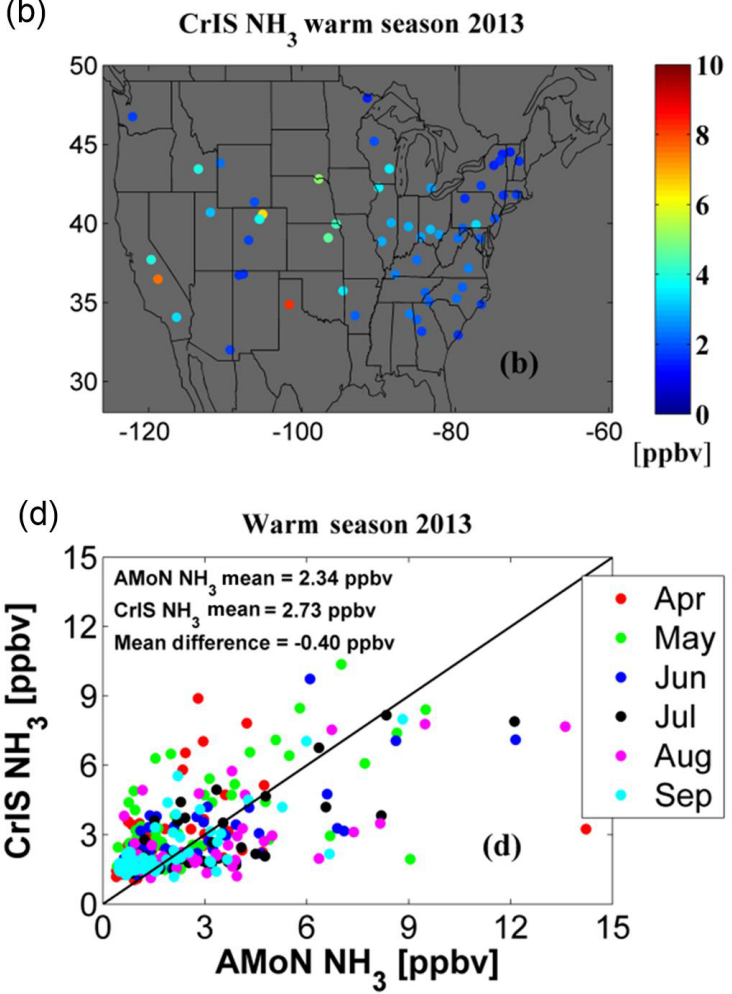

Figure 7. Comparisons of the measured surface $\mathrm{NH}_{3}$ concentration by the $\mathrm{AMoN}$ and CrIS-derived surface $\mathrm{NH}_{3}$ concentration in the US during the warm season (April-September) in 2013 (Kharol et al., 2018). (a) and (b) indicate measured and CrIS-derived surface $\mathrm{NH}_{3}$ concentration at the AMoN sites, respectively; (c) represents the comparison of averaged surface $\mathrm{NH}_{3}$ concentration during warm months between CrIS-derived estimates and measurements, while (d) indicates the comparison of monthly surface $\mathrm{NH}_{3}$ concentration between CrIS-derived estimates and measurements.

(a)

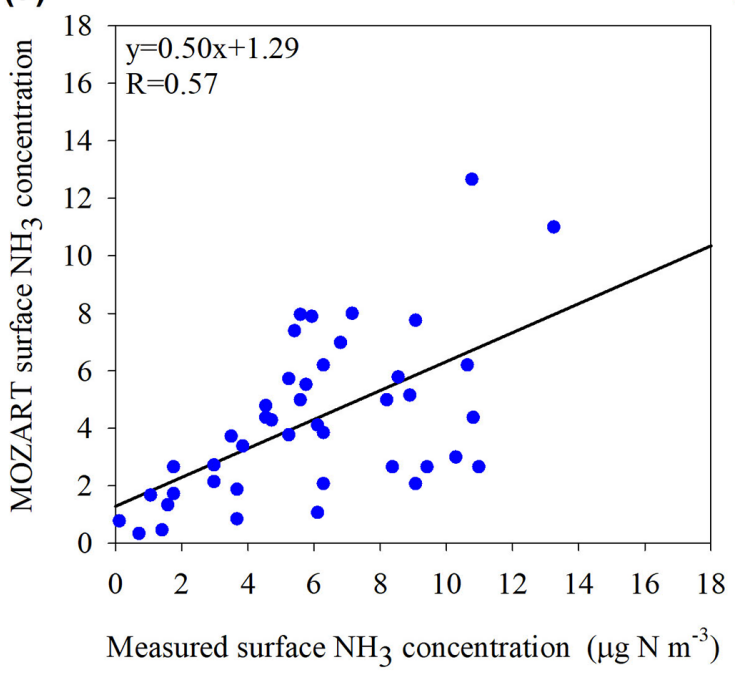

(b)

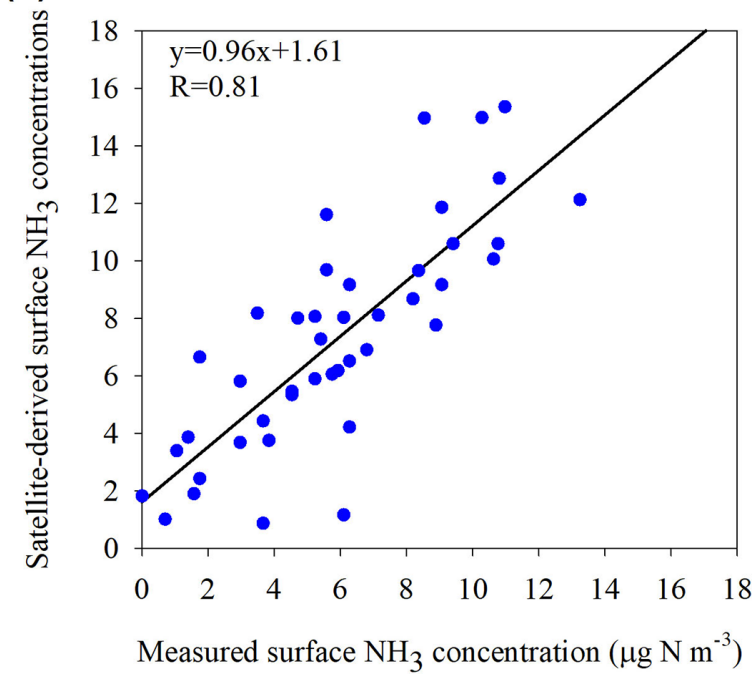

Figure 8. Comparisons of the measured surface $\mathrm{NH}_{3}$ concentration with IASI-derived surface $\mathrm{NH}_{3}$ concentration at the NNDMN sites over China (Liu et al., 2017b). (a) indicates the comparison of measured and modeled surface $\mathrm{NH}_{3}$ concentration from an ACTM (MOZART), and (b) represents the comparison of the measured and IASI-derived surface $\mathrm{NH}_{3}$ concentration. 


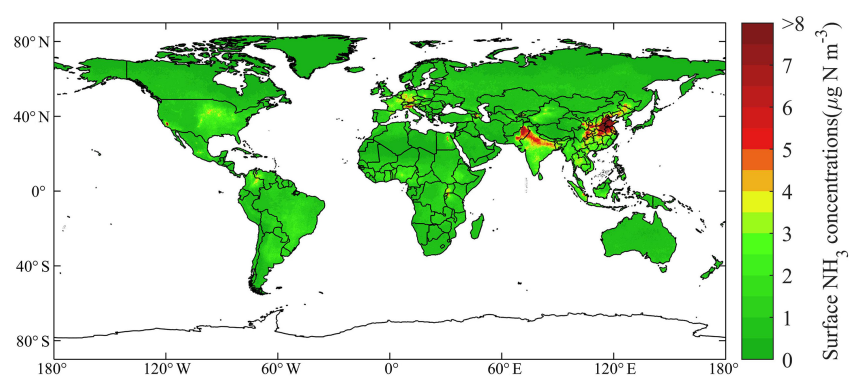

Figure 9. Spatially satellite-based surface $\mathrm{NH}_{3}$ estimates in 2014 (Liu et al., 2019). The global surface $\mathrm{NH}_{3}$ concentration datasets have been released on the website: https://zenodo.org/record/ 3546517\#.Xj6I4GgzY2w, last access: 17 July 2020.

easily used to estimate satellite-derived $\mathrm{NH}_{3}$ concentration at any height. We can also estimate dry $\mathrm{NH}_{3}$ deposition using the IASI-derived surface $\mathrm{NH}_{3}$ concentration combining the modeled $V_{\mathrm{d}}$. For the dry deposition, the uncertainty mainly came from the satellite-derived estimates using the modeled vertical profiles. The uncertainty of vertical profiles modeled by the ACTM mainly resulted from the chemical and transport mechanisms. We recommend using the Gaussian function to determine the height of surface $\mathrm{NO}_{2}$ and $\mathrm{NH}_{3}$ concentrations that best matched with the ground-based measurements. There may exist systematic biases by simply using the relationship of $\mathrm{NO}_{2}$ columns and surface concentration to estimate satellite surface $\mathrm{NO}_{2}$ concentrations. To date, there are still no studies developing satellite-based methods to estimate the wet reduced $\mathrm{N}_{\mathrm{r}}$ deposition on a regional scale.

\section{Trends of surface $N_{r}$ concentration and deposition by satellite-based methods}

The $\mathrm{N}_{\mathrm{r}}$ concentration and deposition modeled by ACTMs are highly dependent on the accuracy of input $\mathrm{N}_{\mathrm{r}}$ emissions. The methods commonly used to estimate anthropogenic $\mathrm{N}_{\mathrm{r}}$ emissions are based on the data of human activities and emission factors, which can be highly uncertain. The ACTM methods driven by the $\mathrm{N}_{\mathrm{r}}$ emission inventory have relatively poor timeliness and have limitations in monitoring the recent trends of $\mathrm{N}_{\mathrm{r}}$ deposition.

Satellite-based methods provide a simple, fast and relatively objective way to monitor $\mathrm{N}_{\mathrm{r}}$ deposition at a high resolution and are less susceptible to the errors in the assumptions that emission inventories are based on, particularly the lack of reliable data on developing countries (Crippa et al., 2018). With such advantages, researchers developed the satellitebased methods to estimate surface $\mathrm{N}_{\mathrm{r}}$ concentration, deposition and even emissions. Satellite-based methods have advantages in monitoring the recent trends of $\mathrm{N}_{\mathrm{r}}$ deposition. Geddes et al. (2016) used the $\mathrm{NO}_{2}$ column from GOME, SCIAMACHY, and GOME-2 to estimate satellite-derived $\mathrm{NO}_{x}$ emissions and then used the calibrated $\mathrm{NO}_{x}$ emission inventory to drive an ACTM to simulate the long-term oxidized $\mathrm{N}_{\mathrm{r}}$ deposition globally (Geddes and Martin, 2017). They found oxidized $N_{r}$ deposition from 1996 to 2014 decreased by $60 \%$ in the eastern US, doubled in eastern China, and declined by $20 \%$ in western Europe (Fig. 12). We use the datasets by Geddes et al. (2016) to calculate the trends of total oxidized $\mathrm{N}_{\mathrm{r}}$ deposition during 1996-2014 (Geddes and Martin, 2017). It is obvious that two completely opposite trends exist: (1) in eastern China with a steep increase of higher than $0.5 \mathrm{~kg} \mathrm{Nha}^{-1} \mathrm{yr}^{-1}$ and (2) in eastern US with a steep decrease of lower than $-0.5 \mathrm{~kg} \mathrm{~N} \mathrm{ha}^{-1} \mathrm{yr}^{-1}$. Although it is not a direct way to use satellite $\mathrm{N}_{\mathrm{r}}$ observation to estimate $\mathrm{N}_{\mathrm{r}}$ deposition, the method of estimating trends of $\mathrm{N}_{\mathrm{r}}$ deposition by Geddes et al. (2016) can be considered effective since it took account of the changes in both $\mathrm{NO}_{x}$ emission and climate by an ACTM (Geddes and Martin, 2017).

Some researchers developed a more direct way to infer the trends of surface $\mathrm{N}_{\mathrm{r}}$ concentration and deposition. Geddes et al. (2016) presented a comprehensive long-term global surface $\mathrm{NO}_{2}$ concentration estimate (at $0.1^{\circ}$ resolution using an oversampling approach) between 1996 and 2012 by using the $\mathrm{NO}_{2}$ column from GOME, SCIAMACHY, and GOME2 (Geddes et al., 2016). The surface $\mathrm{NO}_{2}$ concentration in North America (the US and Canada) decreased steeply, followed by western Europe, Japan and South Korea, but approximately tripled in China and North Korea (Geddes et al., 2016). Jia et al. (2016) established a simple linear regression model based on the $\mathrm{OMI} \mathrm{NO}_{2}$ column and ground-based surface $\mathrm{N}_{\mathrm{r}}$ concentration and then estimated the trends of dry $\mathrm{N}_{\mathrm{r}}$ deposition globally between 2005 and 2014 (Jia et al., 2016). They found that dry $\mathrm{N}_{\mathrm{r}}$ deposition in eastern China increased rapidly, while in the eastern US, western Europe, and Japan dry $\mathrm{N}_{\mathrm{r}}$ deposition has decreased in recent decades.

We used the proposed framework to estimate the long-term surface $\mathrm{NO}_{2}$ concentrations by OMI during 2005-2016. Note that the simulated profile function has a general rule, which can be well simulated by a Gaussian function for any year (for our case during 2005-2016). The emission inventories should not affect the vertical profile shapes using a Gaussian function, but the transport and chemical mechanism in the CTM may affect the accuracy of the vertical profile distribution. The satellite-based methods did not need to rely on the accuracy of the statistical emission data. We split the time span of 2005-2016 into two periods, 2005-2011 and 2011-2016, as surface $\mathrm{NO}_{2}$ concentration shows the opposite trend in China in these two periods. The magnitudes of both growth and decline in surface $\mathrm{NO}_{2}$ concentration in China are most pronounced worldwide in the two periods (Fig. 13). During 2005-2011, apart from eastern China with the largest increase in surface $\mathrm{NO}_{2}$ concentration, there are also several areas with increasing trends, such as northwestern and eastern India (New Delhi and Orissa), western Russia, eastern Europe (northern Italy), western US (Colorado and Utah), northwestern US (Seattle and Portland), southwestern Canada (Vancouver, Edmonton, Calgary), northeast- 

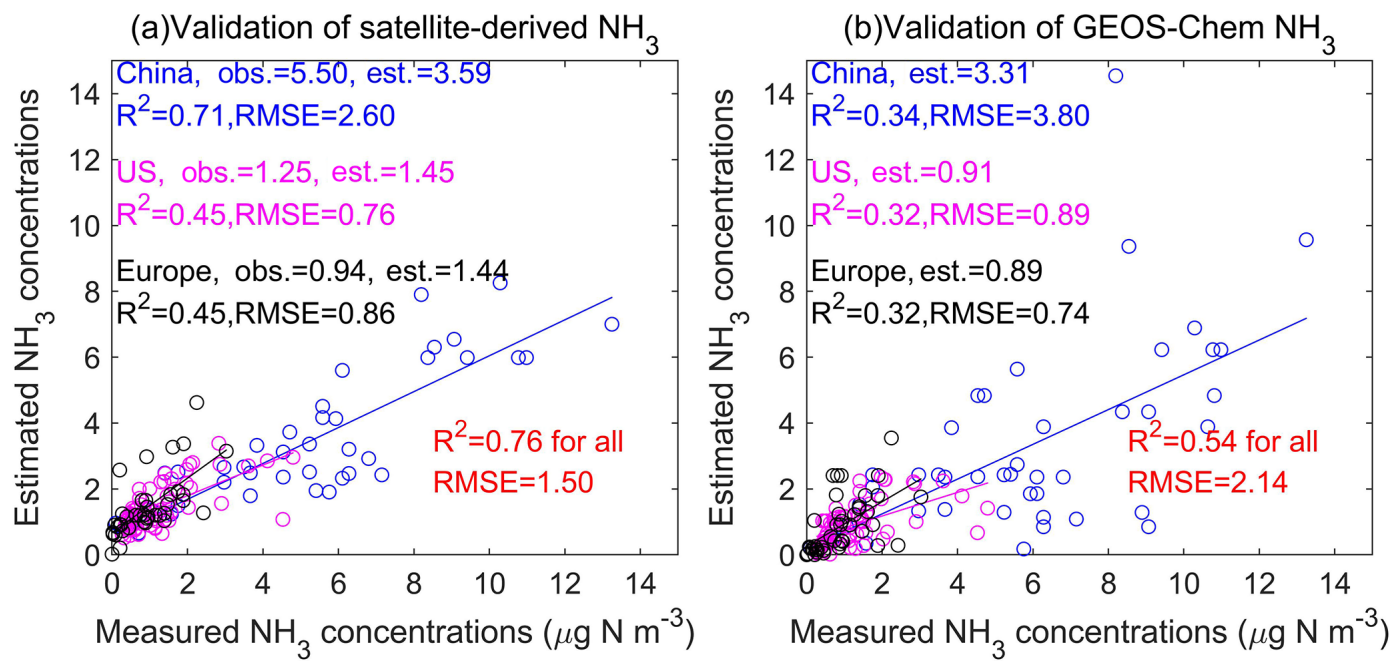

Figure 10. Comparison between yearly satellite-based and measured surface $\mathrm{NH}_{3}$ concentrations (a) and comparison between yearly modeling (by an ACTM as GEOS-Chem) and measured surface $\mathrm{NH}_{3}$ concentrations (b) (Liu et al., 2019). The ground-based monitoring sites are shown in Fig. 4.

(a) $\mathrm{R}^{2}$ of Gussian simulation for $\mathrm{NO}_{2}$ verticle profile

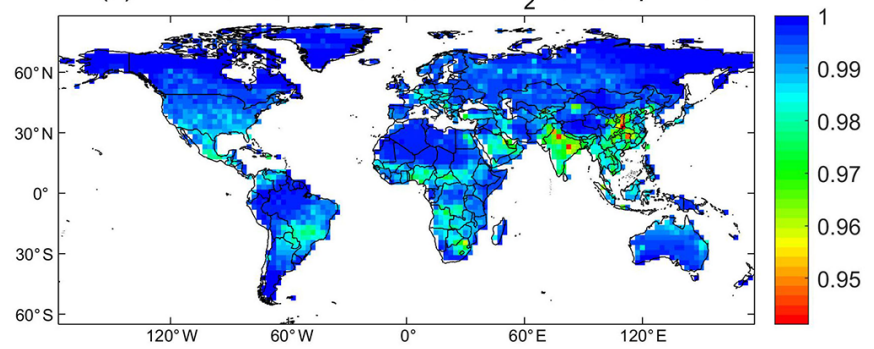

(b) $\mathrm{R}^{2}$ of Gussian simulation for $\mathrm{NH}_{3}$ verticle profile

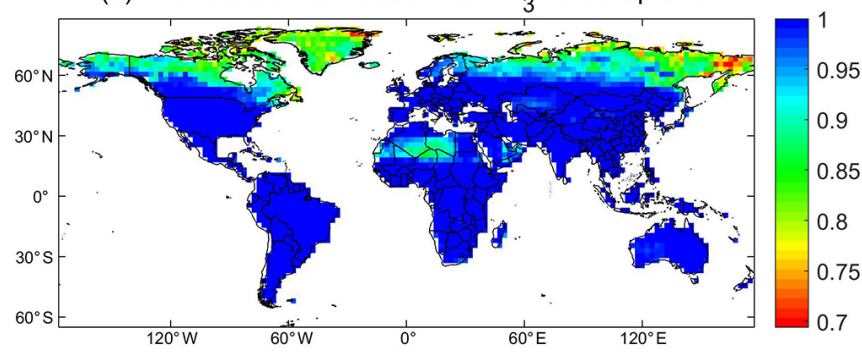

Figure 11. Spatial distributions of $R^{2}$ for a Gaussian function by simulating $\mathrm{NH}_{3}$ and $\mathrm{NO}_{2}$ vertical profiles. This is an example of Gaussian fitting using 47 layers' $\mathrm{NH}_{3}$ and $\mathrm{NO}_{2}$ concentration from an ACTM (GEOS-Chem).

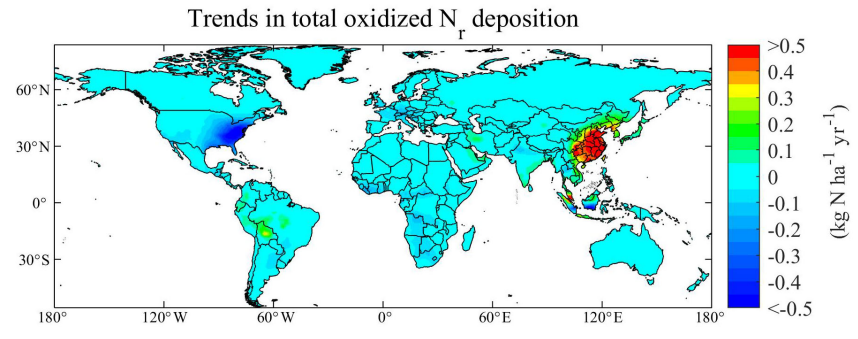

Figure 12. Gridded annual changes in total oxidized $\mathrm{N}_{\mathrm{r}}$ deposition simulated by GEOS-Chem constrained with GOME, SCIAMACHY, and GOME-2 $\mathrm{NO}_{2}$ retrievals during 1996-2014 (Geddes and Martin, 2017). We gained the generated datasets (http://fizz.phys.dal.ca/ atmos/martin/?page_id=1520, last access: 17 July 2020) by Geddes et al. (2016) and calculated the trends using the linear methods. ern Pakistan and northwestern Xinjiang (Urumqi). Notably, the biggest decreases in surface $\mathrm{NO}_{2}$ concentration during 2005-2011 occurred in the eastern US and western EU (North France, southern England, and western Germany). During 2011-2016, due to the strict control of $\mathrm{NO}_{x}$ emissions, eastern China had the largest decrease in surface $\mathrm{NO}_{2}$ concentration than elsewhere worldwide, followed by western Xinjiang, western Europe and some areas in western Russia.

Liu et al. (2019) estimated surface $\mathrm{NH}_{3}$ concentration globally during 2008-2016 using satellite $\mathrm{NH}_{3}$ retrievals by IASI (Liu et al., 2019). A large increase in surface $\mathrm{NH}_{3}$ concentrations was found in eastern China, followed by northern Xinjiang Province in China during 2008-2016 (Fig. 14). Satellite-based methods have been proven as an effective and unique way to monitor the trends of global $\mathrm{N}_{\mathrm{r}}$ concentration and deposition. To date, there are still few studies reporting the satellite-derived trends of reduced $\mathrm{N}_{\mathrm{r}}$ deposition on a global scale. 
(a)Trends in surface $\mathrm{NO}_{2}$ during 2005-2011

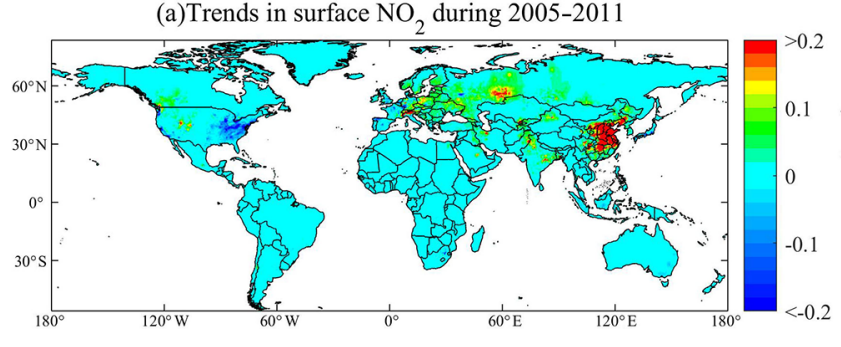

(b)Trends in surface $\mathrm{NO}_{2}$ during 2011-2016

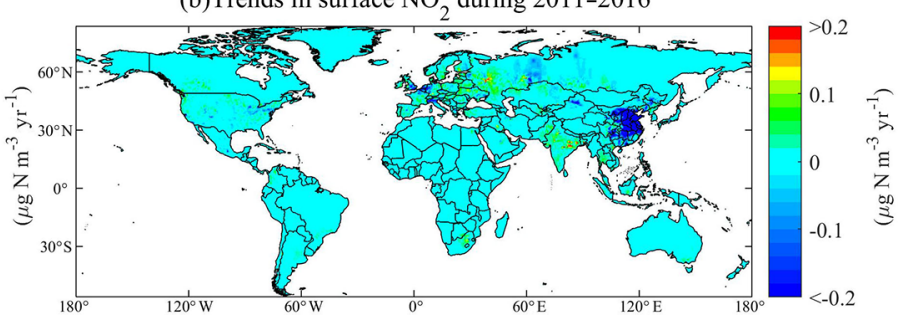

Figure 13. Gridded annual changes in surface $\mathrm{NO}_{2}$ concentrations gained by OMI retrievals during 2005-2011 (a) and during 2011-2016 (b) in this study. We have released the global surface $\mathrm{NO}_{2}$ concentrations during 2005-2016 available at the website: https://zenodo.org/ record/3546517\#.Xj6I4GgzY2w, last access: 17 July 2020.

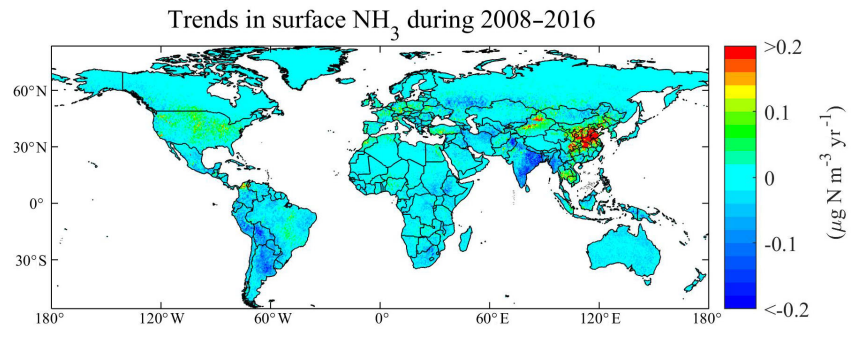

Figure 14. Gridded annual changes in surface $\mathrm{NH}_{3}$ concentrations gained by IASI retrievals during 2008-2016 (Liu et al., 2019). We have released the global surface $\mathrm{NH}_{3}$ concentrations during 2008-2016 at the website: https://zenodo.org/record/3546517\# .Xj6I4GgzY2w, last access: 17 July 2020.

\section{Remaining challenges for estimating $\mathrm{N}_{\mathrm{r}}$ deposition using satellite observation}

First, the reduced $\mathrm{N}_{\mathrm{r}}$ deposition makes an important contribution to total $\mathrm{N}_{\mathrm{r}}$ deposition. $\mathrm{NH}_{3}$ exhibits bi-directional airsurface exchanges. The $\mathrm{NH}_{3}$ compensation point (Farquhar et al., 1980) is also an important and highly variable factor controlling dry $\mathrm{NH}_{3}$ deposition (Schrader et al., 2016; Zhang et al., 2010). However, the current existing satellite-based methods did not consider this bi-directional air-surface exchange. It is important to better parameterize the $\mathrm{NH}_{3}$ compensation point and assess the effects of bi-directional airsurface exchanges on estimating the dry $\mathrm{NH}_{3}$ deposition.

Second, the existing satellite-based methods to estimate $\mathrm{N}_{\mathrm{r}}$ deposition used the ratio of the surface $\mathrm{N}_{\mathrm{r}}$ concentration to the $\mathrm{N}_{\mathrm{r}}$ column by an ACTM to convert satellite $\mathrm{N}_{\mathrm{r}}$ column to surface $\mathrm{N}_{\mathrm{r}}$ concentration. However, the calculated ratio (by an ACTM) and the satellite $\mathrm{N}_{\mathrm{r}}$ column have different spatial resolutions, and previous studies usually applied the modeled ratio directly or interpolated the ratio into the resolution of the satellite $\mathrm{N}_{\mathrm{r}}$ column. This method assumes the relationship at coarse resolution by an ACTM can also be effective at fine resolution, as the satellite indicated. When regional studies are conducted, regional ACTMs coupled with another meteorological model (e.g., WRF-Chem, WRF-CMAQ) (Grell et al., 2005; Wong et al., 2012) can be configured to match the spatial resolution of satellite observation, but this is not as viable for global ACTMs (e.g., MOZART, GEOS-Chem) due to differences in model structures and computational cost. The modeled ratio of surface $\mathrm{N}_{\mathrm{r}}$ concentration to the $\mathrm{N}_{\mathrm{r}}$ column may have variability at spatial scales finer than the horizontal resolution of global ACTMs. The impact of such a scale effect (at different spatial scales) on estimated surface $\mathrm{N}_{\mathrm{r}}$ concentration should be further studied.

Third, the satellite observation can only obtain a reliable $\mathrm{NO}_{2}$ and $\mathrm{NH}_{3}$ column presently, and there are no available high-resolution and reliable direct $\mathrm{HNO}_{3}, \mathrm{NO}_{3}^{-}$, and $\mathrm{NH}_{4}^{+}$retrievals. For $\mathrm{HNO}_{3}, \mathrm{NO}_{3}^{-}$, and $\mathrm{NH}_{4}^{+}$concentrations, the satellite-based methods often applied the satellite-derived $\mathrm{NO}_{2}$ and $\mathrm{NH}_{3}$ concentration and the relationship between $\mathrm{N}_{\mathrm{r}}$ species from an ACTM (or ground-based measurements) to estimate surface $\mathrm{HNO}_{3}, \mathrm{NO}_{3}^{-}$, and $\mathrm{NH}_{4}^{+}$concentration. With the development of satellite technology, more and more $\mathrm{N}_{\mathrm{r}}$ species can be detected, such as $\mathrm{HNO}_{3}$. However, at present, satellite $\mathrm{HNO}_{3}$ products are not mature, and the spatial resolution is low. Direct, high-resolution and reliable satellite monitoring of more $\mathrm{N}_{\mathrm{r}}$ species is critical to further developing the use of atmospheric remote sensing to estimate $\mathrm{N}_{\mathrm{r}}$ deposition at global and regional scales.

Fourth, estimating wet $\mathrm{N}_{\mathrm{r}}$ deposition using the satellite $\mathrm{NO}_{2}$ and $\mathrm{NH}_{3}$ column remains relatively uncommon. Further studies should focus on how to combine the high-resolution satellite $\mathrm{NO}_{2}$ and $\mathrm{NH}_{3}$ column and the ground-based monitoring data to build wet $\mathrm{N}_{\mathrm{r}}$ deposition models to estimate wet $\mathrm{N}_{\mathrm{r}}$ deposition at a higher spatiotemporal resolution. The proposed scheme to estimate the wet $\mathrm{N}_{\mathrm{r}}$ deposition in Sect. 3 is statistical. As far as we know, previous studies using the satellite $\mathrm{NO}_{2}$ and $\mathrm{NH}_{3}$ column to estimate wet $\mathrm{N}_{\mathrm{r}}$ deposition used a statistical way, and no studies were done from a mechanism perspective. The wet $\mathrm{N}_{\mathrm{r}}$ deposition includes the scavenging processes of in-cloud, under-cloud and precipitation. Processed-level knowledge and models can benefit the estimation of wet $\mathrm{N}_{\mathrm{r}}$ deposition using the satellite $\mathrm{NO}_{2}$ and $\mathrm{NH}_{3}$ column. 


\section{Conclusions}

The recent advances of satellite-based methods for estimating surface $\mathrm{N}_{\mathrm{r}}$ concentration and deposition have been reviewed. Previous studies have focused on using the satellite $\mathrm{NO}_{2}$ column to estimate surface $\mathrm{NO}_{2}$ concentrations and dry $\mathrm{NO}_{2}$ deposition both regionally and globally. The research on calculating surface $\mathrm{NH}_{3}$ concentration and reduced $\mathrm{N}_{\mathrm{r}}$ deposition by satellite $\mathrm{NH}_{3}$ data is just beginning, and some scholars have carried out estimations of surface $\mathrm{NH}_{3}$ concentration and dry $\mathrm{NH}_{3}$ deposition on different spatial and temporal scales, but the research degree is still relatively low. We present a framework of using the satellite $\mathrm{NO}_{2}$ and $\mathrm{NH}_{3}$ column to estimate $\mathrm{N}_{\mathrm{r}}$ deposition based on recent advances. The proposed framework of using a Gaussian function to model vertical $\mathrm{NO}_{2}$ and $\mathrm{NH}_{3}$ profiles can be used to convert the satellite $\mathrm{NO}_{2}$ and $\mathrm{NH}_{3}$ column to surface $\mathrm{NO}_{2}$ and $\mathrm{NH}_{3}$ concentration at any height simply and quickly. The proposed framework of using the satellite $\mathrm{NO}_{2}$ and $\mathrm{NH}_{3}$ column to estimate wet $\mathrm{N}_{\mathrm{r}}$ deposition is a statistical way, and further studies should be done from a mechanism perspective. Finally, we summarized current challenges of using the satellite $\mathrm{NO}_{2}$ and $\mathrm{NH}_{3}$ column to estimate surface $\mathrm{N}_{\mathrm{r}}$ concentration and deposition, including a lack of considering $\mathrm{NH}_{3}$ bidirectional air-surface exchanges and the problem of different spatial scales between an ACTM and satellite observation.

Data availability. OMI $\mathrm{NO}_{2}$ datasets are available at http://www. temis.nl/airpollution/no2.html, last access: 17 July 2020. IASI $\mathrm{NH}_{3}$ datasets are available at https://cds-espri.ipsl.upmc.fr/etherTypo/ index.php?id $=1700 \& \mathrm{~L}=1$, last access: 17 July 2020. Surface $\mathrm{NO}_{2}$ concentration during 2005-2007 obtained by Nowlan et al. (2014) and long-term estimates (1996-2012) by Geddes et al. (2016) are available at http://fizz.phys.dal.ca/ atmos/martin/?page_id= 232, last access: 17 July 2020. Total oxidized $\mathrm{N}_{\mathrm{r}}$ deposition simulated by GEOS-Chem constrained with GOME, SCIAMACHY, and GOME-2 $\mathrm{NO}_{2}$ retrievals during 1996-2014 (Geddes and Martin, 2017) is available at http://fizz.phys.dal.ca/ atmos/martin/?page_ $\mathrm{id}=1520$, last access: 17 July 2020. A database of atmospheric $\mathrm{N}_{\mathrm{r}}$ concentration and deposition from the nationwide monitoring network in China is available at https://www.nature.com/articles/ s41597-019-0061-2, last access: 17 July 2020. Measured $N_{r}$ concentration and deposition datasets in the United States are available on the website: https://www.epa.gov/outdoor-air-quality-data, last access: 17 July 2020. Measured surface $\mathrm{NO}_{2}$ and $\mathrm{NH}_{3}$ concentration datasets in Europe are available at https://www.nilu.no/ projects/ccc/emepdata.html, last access: 17 July 2020. Global surface $\mathrm{NO}_{2}$ and $\mathrm{NH}_{3}$ concentration data used to calculate the longterm trends in Fig. 13 and Fig. 14 have been released on the website: https://zenodo.org/record/3546517\#.Xj6I4GgzY2w, last access: 17 July 2020.

Author contributions. LL designed this study. LL, YYY and WX conducted the data analysis. All the co-authors contributed to the revision of the paper.
Competing interests. The authors declare that they have no conflict of interest.

Acknowledgements. This study is supported by the National Natural Science Foundation of China (nos. 41471343, 41425007, and 41101315) and the Chinese National Programs on Heavy Air Pollution Mechanisms and Enhanced Prevention Measures (Project no. 8 in the 2nd Special Program). The analysis in this study is supported by the Supercomputing Center of Lanzhou University.

Financial support. This research has been supported by the National Natural Science Foundation of China (grant nos. 41471343, 41425007, and 41101315).

Review statement. This paper was edited by Eliza Harris and reviewed by two anonymous referees.

\section{References}

Amos, H. M., Jacob, D. J., Holmes, C. D., Fisher, J. A., Wang, Q., Yantosca, R. M., Corbitt, E. S., Galarneau, E., Rutter, A. P., Gustin, M. S., Steffen, A., Schauer, J. J., Graydon, J. A., Louis, V. L. St., Talbot, R. W., Edgerton, E. S., Zhang, Y., and Sunderland, E. M.: Gas-particle partitioning of atmospheric $\mathrm{Hg}$ (II) and its effect on global mercury deposition, Atmos. Chem. Phys., 12, 591-603, https://doi.org/10.5194/acp-12-591-2012, 2012.

Atmospheric Spectroscopy Group at Université libre de Bruxelles: available at: https://cds-espri.ipsl.upmc.fr/etherTypo/index.php? id=1700\&L=1, last access: 17 July 2020.

Atmospheric Composition Analysis Group at Dalhousie University: available at: http://fizz.phys.dal.ca/ atmos/martin/?page_id=232 and http://fizz.phys.dal.ca/ atmos/martin/?page_id=1520, last access: 17 July 2020.

Beer, R., Shephard, M. W., Kulawik, S. S., Clough, S. A., Eldering, A., Bowman, K. W., Sander, S. P., Fisher, B. M., Payne, V. H., Luo, M., Osterman, G. B., and Worden, J. R.: First satellite observations of lower tropospheric ammonia and methanol, Geophys. Res Lett., 35, 1-5, https://doi.org/10.1029/2008GL033642, 2008.

Bobbink, R., Hicks, K., Galloway, J., Spranger, T., Alkemade, R., Ashmore, M., Bustamante, M., Cinderby, S., Davidson, E., Dentener, F., Emmett, B., Erisman, J.-W., Fenn, M., Gilliam, F., Nordin, A., Pardo, L., and De Vries, W.: Global assessment of nitrogen deposition effects on terrestrial plant diversity: a synthesis, Ecol. Appl., 20, 30-59, https://doi.org/10.1890/08-1140.1, 2010.

Boersma, K. F., Eskes, H. J., Dirksen, R. J., van der A, R. J., Veefkind, J. P., Stammes, P., Huijnen, V., Kleipool, Q. L., Sneep, M., Claas, J., Leitão, J., Richter, A., Zhou, Y., and Brunner, D.: An improved tropospheric $\mathrm{NO}_{2}$ column retrieval algorithm for the Ozone Monitoring Instrument, Atmos. Meas. Tech., 4, 19051928, 10.5194/amt-4-1905-2011, 2011.

Canfield, D. E., Glazer, A. N., and Falkowski, P. G.: The evolution and future of Earth's nitrogen cycle, Science, 330, 192-196, 2010 . 
Cao, G. L., Zhang, X. Y., and Gong, S. L.: Emission inventories of primary particles and pollutant gases for China, Sci. Bull., 56, 781-788, 2011.

Cheng, M., Jiang, H., Guo, Z., Zhang, X., and Lu, X.: Estimating $\mathrm{NO}_{2}$ dry deposition using satellite data in eastern China, Int. J. Remote Sens., 34, 2548-2565, 2013.

China Agricultural University: available at: https://www.nature. com/articles/s41597-019-0061-2, last access: 17 July 2020.

Coheur, P.-F., Clarisse, L., Turquety, S., Hurtmans, D., and Clerbaux, C.: IASI measurements of reactive trace species in biomass burning plumes, Atmos. Chem. Phys., 9, 5655-5667, https://doi.org/10.5194/acp-9-5655-2009, 2009.

Crippa, M., Guizzardi, D., Muntean, M., Schaaf, E., Dentener, F., van Aardenne, J. A., Monni, S., Doering, U., Olivier, J. G. J., Pagliari, V., and Janssens-Maenhout, G.: Gridded emissions of air pollutants for the period 1970-2012 within EDGAR v4.3.2, Earth Syst. Sci. Data, 10, 1987-2013, https://doi.org/10.5194/essd-10-1987-2018, 2018.

Dammers, E., Palm, M., Van Damme, M., Vigouroux, C., Smale, D., Conway, S., Toon, G. C., Jones, N., Nussbaumer, E., Warneke, T., Petri, C., Clarisse, L., Clerbaux, C., Hermans, C., Lutsch, E., Strong, K., Hannigan, J. W., Nakajima, H., Morino, I., Herrera, B., Stremme, W., Grutter, M., Schaap, M., Wichink Kruit, R. J., Notholt, J., Coheur, P. F., and Erisman, J. W.: An evaluation of IASI-NH 3 with ground-based Fourier transform infrared spectroscopy measurements, Atmos. Chem. Phys., 16, 10351-10368, https://doi.org/10.5194/acp-16-10351-2016, 2016.

Emmons, L. K., Walters, S., Hess, P. G., Lamarque, J.-F., Pfister, G. G., Fillmore, D., Granier, C., Guenther, A., Kinnison, D., Laepple, T., Orlando, J., Tie, X., Tyndall, G., Wiedinmyer, C., Baughcum, S. L., and Kloster, S.: Description and evaluation of the Model for Ozone and Related chemical Tracers, version 4 (MOZART-4), Geosci. Model Dev., 3, 43-67, https://doi.org/10.5194/gmd-3-43-2010, 2010.

Erisman, J. W., Sutton, M. A., Galloway, J., Klimont, Z., and Winiwarter, W.: How a century of ammonia synthesis changed the world, Nat. Geosci., 1, 636-639, 2008.

European Monitoring and Evaluation Programme: available at: https://www.nilu.no/projects/ccc/emepdata.html, last access: 17 July 2020.

Farquhar, G. D., Firth, P. M., Wetselaar, R., and Weir, B.: On the Gaseous Exchange of Ammonia between Leaves and the Environment: Determination of the Ammonia Compensation Point, Plant Physiol., 66, 710-714, https://doi.org/10.1104/pp.66.4.710, 1980.

Fowler, D., Coyle, M., Skiba, U., Sutton, M. A., Cape, J. N., Reis, S., Sheppard, L. J., Jenkins, A., Grizzetti, B., Galloway, J. N., Vitousek, P., Leach, A., Bouwman, A. F., Butterbach-Bahl, K., Dentener, F., Stevenson, D., Amann, M., and Voss, M.: The global nitrogen cycle in the twentyfirst century, Philos. T. R. Soc. Lond., 368, 20130164, https://doi.org/10.1098/rstb.2013.0164, 2013.

Galloway, J. N., Dentener, F. J., Capone, D. G., Boyer, E. W., Howarth, R. W., Seitzinger, S. P., Asner, G. P., Cleveland, C., Green, P., and Holland, E.: Nitrogen cycles: past, present, and future, Biogeochemistry, 70, 153-226, 2004a.

Galloway, J. N., Dentener, F. J., Capone, D. G., Boyer, E. W., Howarth, R. W., Seitzinger, S. P., Asner, G. P., Cleveland, C. C., Green, P. A., Holland, E. A., Karl, D. M., Michaels, A. F.,
Porter, J. H., Townsend, A. R., and Vöosmarty, C. J.: Nitrogen Cycles: Past, Present, and Future, Biogeochemistry, 70, 153-226, https://doi.org/10.1007/s10533-004-0370-0, 2004b.

Galloway, J. N., Townsend, A. R., Erisman, J. W., Bekunda, M., Cai, Z., Freney, J. R., Martinelli, L. A., Seitzinger, S. P., and Sutton, M. A.: Transformation of the nitrogen cycle: recent trends, questions, and potential solutions, Science, 320, 889-892, 2008.

Geddes, J. A. and Martin, R. V.: Global deposition of total reactive nitrogen oxides from 1996 to 2014 constrained with satellite observations of $\mathrm{NO}_{2}$ columns, Atmos. Chem. Phys., 17, 1007110091, https://doi.org/10.5194/acp-17-10071-2017, 2017.

Geddes, J. A., Martin, R. V., Boys, B. L., and van Donkelaar, A.: Long-term trends worldwide in ambient $\mathrm{NO}_{2}$ concentrations inferred from satellite observations, Environ. Health Persp., 124, 281-289, 2016.

Grell, G. A., Peckham, S. E., Schmitz, R., McKeen, S. A., Frost, G., Skamarock, W. C., and Eder, B.: Fully coupled "online" chemistry within the WRF model, Atmos. Environ., 39, 6957-6975, 2005.

Hoesly, R. M., Smith, S. J., Feng, L., Klimont, Z., JanssensMaenhout, G., Pitkanen, T., Seibert, J. J., Vu, L., Andres, R. J., Bolt, R. M., Bond, T. C., Dawidowski, L., Kholod, N., Kurokawa, J. I., Li, M., Liu, L., Lu, Z., Moura, M. C. P., O'Rourke, P. R., and Zhang, Q.: Historical (1750-2014) anthropogenic emissions of reactive gases and aerosols from the Community Emissions Data System (CEDS), Geosci. Model Dev., 11, 369-408, https://doi.org/10.5194/gmd-11-369-2018, 2018.

Janssens, I. A., Dieleman, W., Luyssaert, S., Subke, J. A., Reichstein, M., Ceulemans, R., Ciais, P., Dolman, A. J., Grace, J., Matteucci, G., Papale, D., Piao, S. L., Schulze, E. D., Tang, J., and Law, B. E.: Reduction of forest soil respiration in response to nitrogen deposition, Nat. Geosci., 3, 315, https://doi.org/10.1038/ngeo844, 2010.

Jia, Y., Yu, G., Gao, Y., He, N., Wang, Q., Jiao, C., and Zuo, Y.: Global inorganic nitrogen dry deposition inferred from groundand space-based measurements, Sci. Rep., 6, 1-11, 2016.

Kharol, S. K., Martin, R. V., Philip, S., Boys, B., Lamsal, L. N., Jerrett, M., Brauer, M., Crouse, D. L., Mclinden, C., and Burnett, R. T.: Assessment of the magnitude and recent trends in satellitederived ground-level nitrogen dioxide over North America, Atmos. Environ., 118, 236-245, 2015.

Kharol, S. K., Shephard, M. W., McLinden, C. A., Zhang, L., Sioris, C. E., O'Brien, J. M., Vet, R., Cady-Pereira, K. E., Hare, E., Siemons, J., and Krotkov, N. A.: Dry Deposition of Reactive Nitrogen From Satellite Observations of Ammonia and Nitrogen Dioxide Over North America, Geophys. Res. Lett., 45, 1157 1166, https://doi.org/10.1002/2017GL075832, 2018.

Kim, T. W., Lee, K., Duce, R., and Liss, P.: Impact of atmospheric nitrogen deposition on phytoplankton productivity in the South China Sea, Geophys. Res Lett., 41, 3156-3162, 2014.

Kuik, F., Lauer, A., Churkina, G., Denier van der Gon, H. A. C., Fenner, D., Mar, K. A., and Butler, T. M.: Air quality modelling in the Berlin-Brandenburg region using WRF-Chem v3.7.1: sensitivity to resolution of model grid and input data, Geosci. Model Dev., 9, 4339-4363, https://doi.org/10.5194/gmd-9-4339-2016, 2016.

Lamarque, J. F., Kiehl, J., Brasseur, G., Butler, T., Cameron-Smith, P., Collins, W., Collins, W., Granier, C., Hauglustaine, D., and Hess, P.: Assessing future nitrogen deposition and carbon cycle 
feedback using a multimodel approach: Analysis of nitrogen deposition, J. Geophys. Res.-Atmos., 110, 1-21, 2005.

Lamsal, L. N., Martin, R. V., van Donkelaar, A., Steinbacher, M., Celarier, E. A., Bucsela, E., Dunlea, E. J., and Pinto, J. P.: Ground-level nitrogen dioxide concentrations inferred from the satellite-borne Ozone Monitoring Instrument, J. Geophys. Res.-Atmos., 113, 1-15, https://doi.org/10.1029/2007JD009235, 2008.

Lamsal, L. N., Martin, R. V., Parrish, D. D., and Krotkov, N. A.: Scaling relationship for $\mathrm{NO}_{2}$ pollution and urban population size: a satellite perspective, Environ. Sci. Technol., 47, 78557861, 2013.

Larkin, A., Geddes, J. A., Martin, R. V., Xiao, Q., Liu, Y., Marshall, J. D., Brauer, M., and Hystad, P.: Global Land Use Regression Model for Nitrogen Dioxide Air Pollution, Environ. Sci. Technol., 51, 6957-6964, 2017.

Larssen, T., Duan, L., and Mulder, J.: Deposition and leaching of sulfur, nitrogen and calcium in four forested catchments in China: implications for acidification, Environ. Sci. Technol., 45, 1192-1198, 2011.

Levine, S. Z. and Schwartz, S. E.: In-cloud and below-cloud scavenging of Nitric acid vapor, Atmos. Environ., 16, 1725-1734, https://doi.org/10.1016/0004-6981(82)90266-9, 1982.

Li, Y., Thompson, T. M., Van Damme, M., Chen, X., Benedict, K. B., Shao, Y., Day, D., Boris, A., Sullivan, A. P., Ham, J., Whitburn, S., Clarisse, L., Coheur, P.-F., and Collett Jr., J. L.: Temporal and spatial variability of ammonia in urban and agricultural regions of northern Colorado, United States, Atmos. Chem. Phys., 17, 6197-6213, https://doi.org/10.5194/acp17-6197-2017, 2017.

Liu, H., Jacob, D. J., Bey, I., and Yantosca, R. M.: Constraints from $210 \mathrm{~Pb}$ and $7 \mathrm{Be}$ on wet deposition and transport in a global threedimensional chemical tracer model driven by assimilated meteorological fields, J. Geophys. Res.-Atmos., 106, 12109-12128, https://doi.org/10.1029/2000JD900839, 2001.

Liu, L., Zhang, X., Xu, W., Liu, X., Lu, X., Chen, D., Zhang, X., Wang, S., and Zhang, W.: Estimation of monthly bulk nitrate deposition in China based on satellite $\mathrm{NO}_{2}$ measurement by the Ozone Monitoring Instrument, Remote Sens. Environ., 199, 93106, 2017a.

Liu, L., Zhang, X., Xu, W., Liu, X., Lu, X., Wang, S., Zhang, W., and Zhao, L.: Ground Ammonia Concentrations over China Derived from Satellite and Atmospheric Transport Modeling, Remote Sens., 9, 1-19, 2017b.

Liu, L., Zhang, X., Zhang, Y., Xu, W., Liu, X., Zhang, X., Feng, J., Chen, X., Zhang, Y., Lu, X., Wang, S., Zhang, W., and Zhao, L.: Dry Particulate Nitrate Deposition in China, Environ. Sci. Technol., 51, 5572-5581, https://doi.org/10.1021/acs.est.7b00898, $2017 \mathrm{c}$.

Liu, L., Zhang, X., Wong, A. Y. H., Xu, W., Liu, X., Li, Y., Mi, H., Lu, X., Zhao, L., Wang, Z., and Wu, X.: Estimating global surface ammonia concentrations inferred from satellite retrievals, Atmos. Chem. Phys., 19, 12051-12066, https://doi.org/10.5194/acp-2019-184, 2019.

Liu, L., Zhang, X., Xu, W., Liu, X., Wei, J., Wang, Z., and Yang, Y.: Global estimates of dry ammonia deposition inferred from space-measurements, Sci. Total Environ., 730, 139189, https://doi.org/10.1016/j.scitotenv.2020.139189, 2020.
Liu, X., Duan, L., Mo, J., Du, E., Shen, J., Lu, X., Zhang, Y., Zhou, X., He, C., and Zhang, F.: Nitrogen deposition and its ecological impact in China: An overview, Environ. Pollut., 159, 2251-2264, https://doi.org/10.1016/j.envpol.2010.08.002, 2011.

Liu, X., Xu, W., Duan, L., Du, E., Pan, Y., Lu, X., Zhang, L., Wu, Z., Wang, X., Zhang, Y., Shen, J., Song, L., Feng, Z., Liu, X., Song, W., Tang, A., Zhang, Y., Zhang, X., and Collett, J. L.: Atmospheric Nitrogen Emission, Deposition, and Air Quality Impacts in China: an Overview, Curr. Pollut. Rep., 3, 65-77, https://doi.org/10.1007/s40726-017-0053-9, 2017.

Lu, X., Jiang, H., Zhang, X., Liu, J., Zhang, Z., Jin, J., Wang, Y., Xu, J., and Cheng, M.: Estimated global nitrogen deposition using $\mathrm{NO}_{2}$ column density, Int. J. Remote Sens., 34, 8893-8906, 2013.

Mari, C., Jacob, D. J., and Bechtold, P.: Transport and scavenging of soluble gases in a deep convective cloud, J. Geophys. Res.Atmos., 105, 22255-22268, 2000.

Nadelhoffer, K. J., Emmett, B. A., Gundersen, P., Kjønaas, O. J., Koopmans, C. J., Schleppi, P., Tietema, A., and Wright, R. F.: Nitrogen deposition makes a minor contribution to carbon sequestration in temperate forests, Nature, 398, 145-148, https://doi.org/10.1038/18205, 1999.

Nemitz, E., Flynn, M., Williams, P. I., Milford, C., Theobald, M. R., Blatter, A., Gallagher, M. W., and Sutton, M. A.: A Relaxed Eddy Accumulation System for the Automated Measurement of Atmospheric Ammonia Fluxes, Water Air Soil Poll., 1, 189-202, https://doi.org/10.1023/A:1013103122226, 2001.

Nicolas, G. and Galloway, J. N.: An Earth-system perspective of the global nitrogen cycle, Nature, 451, 293-296, 2008.

Nowlan, C., Martin, R., Philip, S., Lamsal, L., Krotkov, N., Marais, E., Wang, S., and Zhang, Q.: Global dry deposition of nitrogen dioxide and sulfur dioxide inferred from space-based measurements, Global Biogeochem. Cy., 28, 1025-1043, 2014.

Paerl, H. W., Gardner, W. S., Mccarthy, M. J., Peierls, B. L., and Wilhelm, S. W.: Algal blooms: noteworthy nitrogen, Science, 346, 175-176, 2014.

Pan, Y. P., Wang, Y. S., Tang, G. Q., and Wu, D.: Wet and dry deposition of atmospheric nitrogen at ten sites in Northern China, Atmos. Chem. Phys., 12, 6515-6535, https://doi.org/10.5194/acp12-6515-2012, 2012.

Ronsmans, G., Langerock, B., Wespes, C., Hannigan, J. W., Hase, F., Kerzenmacher, T., Mahieu, E., Schneider, M., Smale, D., Hurtmans, D., De Mazière, M., Clerbaux, C., and Coheur, P. F.: First characterization and validation of FORLI-HNO ${ }_{3}$ vertical profiles retrieved from IASI/Metop, Atmos. Meas. Tech., 9, 4783-4801, https://doi.org/10.5194/amt-9-4783-2016, 2016.

Schrader, F., Brümmer, C., Flechard, C. R., Wichink Kruit, R. J., van Zanten, M. C., Zöll, U., Hensen, A., and Erisman, J. W.: Non-stomatal exchange in ammonia dry deposition models: comparison of two state-of-the-art approaches, Atmos. Chem. Phys., 16, 13417-13430, https://doi.org/10.5194/acp-16-134172016, 2016.

Shen, J., Li, Y., Liu, X., Luo, X., Tang, H., Zhang, Y., and $\mathrm{Wu}$, J.: Atmospheric dry and wet nitrogen deposition on three contrasting land use types of an agricultural catchment in subtropical central China, Atmos. Environ., 67, 415-424, https://doi.org/10.1016/j.atmosenv.2012.10.068, 2013.

Stevens, C. J., Dise, N. B., Mountford, J. O., and Gowing, D. J.: Impact of Nitrogen Deposition on the Species 
Richness of Grasslands, Science, 303, 1876-1879, https://doi.org/10.1126/science.1094678, 2004.

Sutton, M. A., Tang, Y. S., Miners, B., and Fowler, D.: A New Diffusion Denuder System for Long-Term, Regional Monitoring of Atmospheric Ammonia and Ammonium, Water Air Soil Poll., 1, 145-156, 2001.

Tan, J., Fu, J. S., Dentener, F., Sun, J., Emmons, L., Tilmes, S., Sudo, K., Flemming, J., Jonson, J. E., Gravel, S., Bian, H., Davila, Y., Henze, D. K., Lund, M. T., Kucsera, T., Takemura, T., and Keating, T.: Multi-model study of HTAP II on sulfur and nitrogen deposition, Atmos. Chem. Phys., 18, 6847-6866, https://doi.org/10.5194/acp-18-6847-2018, 2018.

TEMIS: available at: http://www.temis.nl/airpollution/no2.html, last access: 17 July 2020.

United States Environmental Protection Agency: available at: https: //www.epa.gov/outdoor-air-quality-data, last access: 17 July 2020.

Van Damme, M., Wichink Kruit, R., Schaap, M., Clarisse, L., Clerbaux, C., Coheur, P. F., Dammers, E., Dolman, A., and Erisman, J.: Evaluating 4 years of atmospheric ammonia $\left(\mathrm{NH}_{3}\right)$ over Europe using IASI satellite observations and LOTOS-EUROS model results, J. Geophys. Res.-Atmos., 119, 9549-9566, 2014.

Van Damme, M., Clarisse, L., Dammers, E., Liu, X., Nowak, J. B., Clerbaux, C., Flechard, C. R., Galy-Lacaux, C., Xu, W., Neuman, J. A., Tang, Y. S., Sutton, M. A., Erisman, J. W., and Coheur, P. F.: Towards validation of ammonia (NH3) measurements from the IASI satellite, Atmos. Meas. Tech., 8, 15751591, https://doi.org/10.5194/amt-8-1575-2015, 2015.

Van der Graaf, S. C., Dammers, E., Schaap, M., and Erisman, J. W.: Technical note: How are $\mathrm{NH}_{3}$ dry deposition estimates affected by combining the LOTOS-EUROS model with IASI-NH satellite observations?, Atmos. Chem. Phys., 18, 13173-13196, https://doi.org/10.5194/acp-18-13173-2018, 2018.

Vet, R., Artz, R. S., Carou, S., Shaw, M., Ro, C.-U., Aas, W., Baker, A., Bowersox, V. C., Dentener, F., Galy-Lacaux, C., Hou, A., Pienaar, J. J., Gillett, R., Forti, M. C., Gromov, S., Hara, H., Khodzher, T., Mahowald, N. M., Nickovic, S., Rao, P. S. P., and Reid, N. W.: A global assessment of precipitation chemistry and deposition of sulfur, nitrogen, sea salt, base cations, organic acids, acidity and pH, and phosphorus, Atmos. Environ., 93, 3100, https://doi.org/10.1016/j.atmosenv.2013.10.060, 2014.

Vitousek, P. M., Aber, J. D., Howarth, R. W., Likens, G. E., Matson, P. A., Schindler, D. W., Schlesinger, W. H., and Tilman, D. G.: Human alteration of the global nitrogen cycle: sources and consequences, Ecol. Appl., 7, 737-750, 1997.

Wei, J., Huang, W., Li, Z., Xue, W., Peng, Y., Sun, L., and Cribb, M.: Estimating 1-km-resolution $\mathrm{PM}_{2.5}$ concentrations across China using the space-time random forest approach, Remote Sens. Environ., 231, 111221, https://doi.org/10.1016/j.rse.2019.111221, 2019.

Wesely, M. and Hicks, B.: Some factors that affect the deposition rates of sulfur dioxide and similar gases on vegetation, Japca $\mathrm{J}$. Air Waste Ma., 27, 1110-1116, 1977.

Whitburn, S., Van Damme, M., Clarisse, L., Bauduin, S., Heald, C. L., Hadji-Lazaro, J., Hurtmans, D., Zondlo, M. A., Clerbaux, C., and Coheur, P. F.: A flexible and robust neural network IASI$\mathrm{NH}_{3}$ retrieval algorithm, J. Geophys. Res.-Atmos., 121, 65816599, https://doi.org/10.1002/2016JD024828, 2016.
Williams, J. E., Boersma, K. F., Le Sager, P., and Verstraeten, W. W.: The high-resolution version of TM5-MP for optimized satellite retrievals: description and validation, Geosci. Model Dev., 10, 721-750, https://doi.org/10.5194/gmd-10-721-2017, 2017.

Wong, D. C., Pleim, J., Mathur, R., Binkowski, F., Otte, T., Gilliam, R., Pouliot, G., Xiu, A., Young, J. O., and Kang, D.: WRFCMAQ two-way coupled system with aerosol feedback: software development and preliminary results, Geosci. Model Dev., 5, 299-312, https://doi.org/10.5194/gmd-5-299-2012, 2012.

Xu, W., Luo, X. S., Pan, Y. P., Zhang, L., Tang, A. H., Shen, J. L., Zhang, Y., Li, K. H., Wu, Q. H., Yang, D. W., Zhang, Y. Y., Xue, J., Li, W. Q., Li, Q. Q., Tang, L., Lu, S. H., Liang, T., Tong, Y. A., Liu, P., Zhang, Q., Xiong, Z. Q., Shi, X. J., Wu, L. H., Shi, W. Q., Tian, K., Zhong, X. H., Shi, K., Tang, Q. Y., Zhang, L. J., Huang, J. L., He, C. E., Kuang, F. H., Zhu, B., Liu, H., Jin, X., Xin, Y. J., Shi, X. K., Du, E. Z., Dore, A. J., Tang, S., Collett Jr., J. L., Goulding, K., Sun, Y. X., Ren, J., Zhang, F. S., and Liu, X. J.: Quantifying atmospheric nitrogen deposition through a nationwide monitoring network across China, Atmos. Chem. Phys., 15, 12345-12360, https://doi.org/10.5194/acp-15-123452015, 2015.

Yu, G., Jia, Y., He, N., Zhu, J., Chen, Z., Wang, Q., Piao, S., Liu, X., He, H., Guo, X., Wen, Z., Li, P., Ding, G., and Goulding, K.: Stabilization of atmospheric nitrogen deposition in China over the past decade, Nat. Geosci., 12, 424-429, https://doi.org/10.1038/s41561-019-0352-4, 2019.

Zhang, L., Wright, L. P., and Asman, W. A. H.: Bi-directional airsurface exchange of atmospheric ammonia: A review of measurements and a development of a big-leaf model for applications in regional-scale air-quality models, J. Geophys. Res.-Atmos., 115, 898-907, 2010.

Zhang, L., Jacob, D. J., Knipping, E. M., Kumar, N., Munger, J. W., Carouge, C. C., van Donkelaar, A., Wang, Y. X., and Chen, D.: Nitrogen deposition to the United States: distribution, sources, and processes, Atmos. Chem. Phys., 12, 4539-4554, https://doi.org/10.5194/acp-12-4539-2012, 2012.

Zhang, Q., Streets, D. G., Carmichael, G. R., He, K. B., Huo, H., Kannari, A., Klimont, Z., Park, I. S., Reddy, S., Fu, J. S., Chen, D., Duan, L., Lei, Y., Wang, L. T., and Yao, Z. L.: Asian emissions in 2006 for the NASA INTEX-B mission, Atmos. Chem. Phys., 9, 5131-5153, https://doi.org/10.5194/acp-9-5131-2009, 2009.

Zhang, X. Y., Lu, X. H., Liu, L., Chen, D. M., Zhang, X. M., Liu, X. J., and Zhang, Y.: Dry deposition of $\mathrm{NO}_{2}$ over China inferred from OMI columnar $\mathrm{NO}_{2}$ and atmospheric chemistry transport model, Atmos. Environ., 169, 238-249, 2017.

Zhang, X. Y., Chuai, X. W., Liu, L., Zhang, W. T., Lu, X. H., Zhao, L. M., and Chen, D. M.: Decadal Trends in Wet Sulfur Deposition in China Estimated From OMI $\mathrm{SO}_{2}$ Columns, J. Geophys. Res.-Atmos., 123, 10796-10811, https://doi.org/10.1029/2018JD028770, 2018.

Zhao, X., Chen, L., and Zhang, H.: Nitrate and ammonia contaminations in drinking water and the affecting factors in Hailun, northeast China, J. Environ. Health, 75, 28-34, 2013.

Zhao, Y., Zhang, L., Chen, Y., Liu, X., Xu, W., Pan, Y., and Duan, L.: Atmospheric nitrogen deposition to China: A model analysis on nitrogen budget and critical load exceedance, Atmos. Environ., 153, 32-40, https://doi.org/10.1016/j.atmosenv.2017.01.018, 2017. 